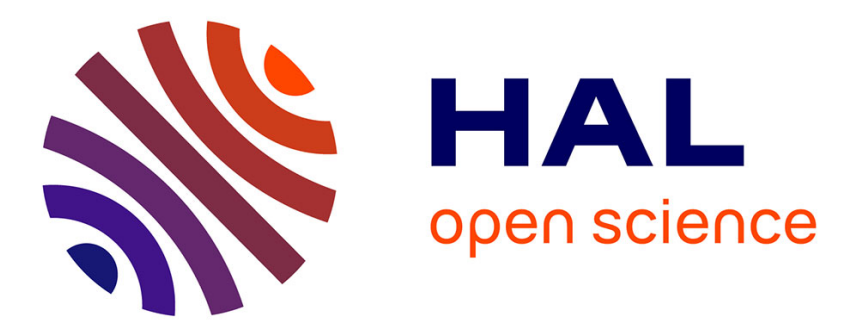

\title{
Hydrographic changes of the Southern Ocean (southeast Indian Sector) Over the last $230 \mathrm{kyr}$
}

Laurent Labeyrie, Monique Labracherie, Nabila Gorfti, Jean Jacques Pichon, Maryline Vautravers, Maurice Arnold, Jean-Claude Duplessy, Martine Paterne, Elizabeth Michel, Josette Duprat, et al.

\section{To cite this version:}

Laurent Labeyrie, Monique Labracherie, Nabila Gorfti, Jean Jacques Pichon, Maryline Vautravers, et al. Hydrographic changes of the Southern Ocean (southeast Indian Sector) Over the last 230 kyr. Paleoceanography, 1996, 11 (1), pp.57-76. 10.1029/95PA02255 . hal-02913419

\section{HAL Id: hal-02913419 https://hal.science/hal-02913419}

Submitted on 6 Feb 2021

HAL is a multi-disciplinary open access archive for the deposit and dissemination of scientific research documents, whether they are published or not. The documents may come from teaching and research institutions in France or abroad, or from public or private research centers.
L'archive ouverte pluridisciplinaire HAL, est destinée au dépôt et à la diffusion de documents scientifiques de niveau recherche, publiés ou non, émanant des établissements d'enseignement et de recherche français ou étrangers, des laboratoires publics ou privés. 


\title{
Hydrographic changes of the Southern Ocean (southeast Indian sector) over the last $230 \mathrm{kyr}$
}

\author{
Laurent Labeyrie, ${ }^{1,2}$ Monique Labracherie, ${ }^{3}$ Nabila Gorfti, ${ }^{1}$ Jean Jacques Pichon, ${ }^{3}$ \\ Maryline Vautravers, ${ }^{3}$ Maurice Arnold, ${ }^{1}$ Jean-Claude Duplessy, ${ }^{1}$ Martine Paterne,' \\ Elizabeth Michel, ${ }^{1}$ Josette Duprat, ${ }^{3}$ Michelle Caralp, ${ }^{3}$ and Jean-Louis Turon ${ }^{3}$
}

\begin{abstract}
Hydrographical changes of the southern Indian Ocean over the last $230 \mathrm{kyr}$, is reconstructed using a 17-m-long sediment core (MD $88770 ; 46^{\circ} 01^{\prime} \mathrm{S} 96^{\circ} 28^{\prime} \mathrm{E}, 3290 \mathrm{~m}$ ). The oxygen and carbon isotopic composition of planktonic ( $N$. pachyderma sinistra and $G$. bulloides) and benthic (Cibicidoudes wuellerstorfi, Epistominella exigua, and Melonis barleeanum) foraminifera have been analysed. Changes in sea surface temperatures (SST) are calculated using diatom and foraminiferal transfer functions. A new core top calibration for the Southern Ocean allows an extension of the method developed in the North Atlantic to estimate paleosalinities (Duplessy et al., 1991). The age scale is built using accelerator mass spectrometry (AMS) ${ }^{14} \mathrm{C}$ dating of $N$. pachyderma s. for the last $35 \mathrm{kyr}$, and an astronomical age scale beyond. Changes in surface temperature and salinity clearly lead (by 3 to $7 \mathrm{kyr}$ ) deep water variations. Thus changes in deep water circulation are not the cause of the early response of the surface Southern Ocean to climatic changes. We suggest that the early warming and cooling of the Southern Ocean result from at least two processes acting in different orbital bands and latitudes: (1) seasonality modulated by obliquity affects the high-latitude ocean surface albedo (sea ice coverage) and heat transfer to and from the atmosphere; (2) low-latitude insolation modulated by precession influences directly the atmosphere dynamic and related precipitation/ evaporation changes, which may significantly change heat transfer to the high southern latitudes, through their control on latitudinal distribution of the major frontal zones and on the conditions of intermediate and deep water formation.
\end{abstract}

\section{Introduction}

The Southern Ocean is a major component of the global climate system, in particular for its role in deep-water circulation and the oceanic carbon cycle [Toggweiler and Sarmiento, 1985]. Yet Southern Ocean hydrographic changes during glacial-interglacial cycles are still poorly known. It has been observed for some time that in Southern Ocean sediment cores, the changes in summer sea surface temperature (SSST) (recorded by the microfossils) lead the changes in northern hemisphere ice sheets volume (recorded in the foraminiferal ${ }^{18} \mathrm{O} /{ }^{16} \mathrm{O}$ ratio) by as much as $5 \mathrm{kyr}$ during the major glacial terminations [Hays et al., 1976; Climate: Long-Range Investigations, Mapping, and Prediction (CLIMAP), 1984; Howard and Prell, 1984, 1992; Labeyrie et al., 1986; Labracherie et al., 1989; Pichon et al., 1992]. The mechanism linking this early response to the northern hemisphere climatic evolution is still not understood. It has been associated to the sensitivity of Southern Ocean surface water to changes in the input of North Atlantic Deep

\footnotetext{
${ }^{1}$ Centre des Faibles Radioactivités, Laboratoire mixte CNRSCEA, Gif/Yvette, France.

${ }^{2}$ Also at Département des Sciences de la Terre, Université Paris-sud Orsay, Orsay, France.

${ }^{3}$ Département de Géologie et Océanographie, URA 197 du CNRS, Université Bordeaux 1, Talence, France.
}

Copyright 1996 by the American Geophysical Union.

Paper number 95PA02255.

0883-8305/96/95PA-02255\$10.00
Water (NADW), itself modulated by Nordic Seas surface [Crowley, 1992; Imbrie et al., 1992]. Because changes in Southern Ocean surface hydrography apparently precede variations in all proxies which are known to influence NADW, Imbrie et al. [1992] proposed that some yet undiscovered process, occurring in the high northern latitudes, reacted faster to northern insolation and influenced the southern waters.

Progress in this field is hampered by the lack of sediment cores representative of the Southern Ocean hydrography which can be analysed for both planktonic and benthic foraminifera. We present in this paper new data from core MD 88-770 $\left(46^{\circ} 01^{\prime} \mathrm{S} 96^{\circ} 28^{\prime} \mathrm{E}, 3290 \mathrm{~m}\right.$ ). The core is located in the same general area as core $\mathrm{RC} 11-120\left(43^{\circ} 31^{\prime} \mathrm{S} 79^{\circ} 52^{\prime} \mathrm{E}\right)$, a reference core for Southern Ocean paleoclimatology (Figure 1). The discussion is mostly based upon the oxygen isotopic analysis of planktonic and benthic foraminifera and sea surface summer temperature (SSST) estimated using foraminiferal and diatom transfer functions. Sea surface salinity is derived from the planktonic foraminiferal $\delta^{18} \mathrm{O}$ and SSST following Duplessy et al. [1991], with a calibration valid for the Southern Ocean. The benthic foraminiferal $\delta^{13} \mathrm{C}$ further constrains the changes in deep water characteristics.

Two main results are derived :

1. Changes in SSST lead the response of Southern Ocean deep water, which indicates that changes in deep thermohaline circulation are not at the origin of the lead of the southern surface hydrography.

2. Sea surface salinities generally increased at the beginning of the surface water warming. This indicates a sudden invasion of subtropical waters from the north. Conversely, cooling 


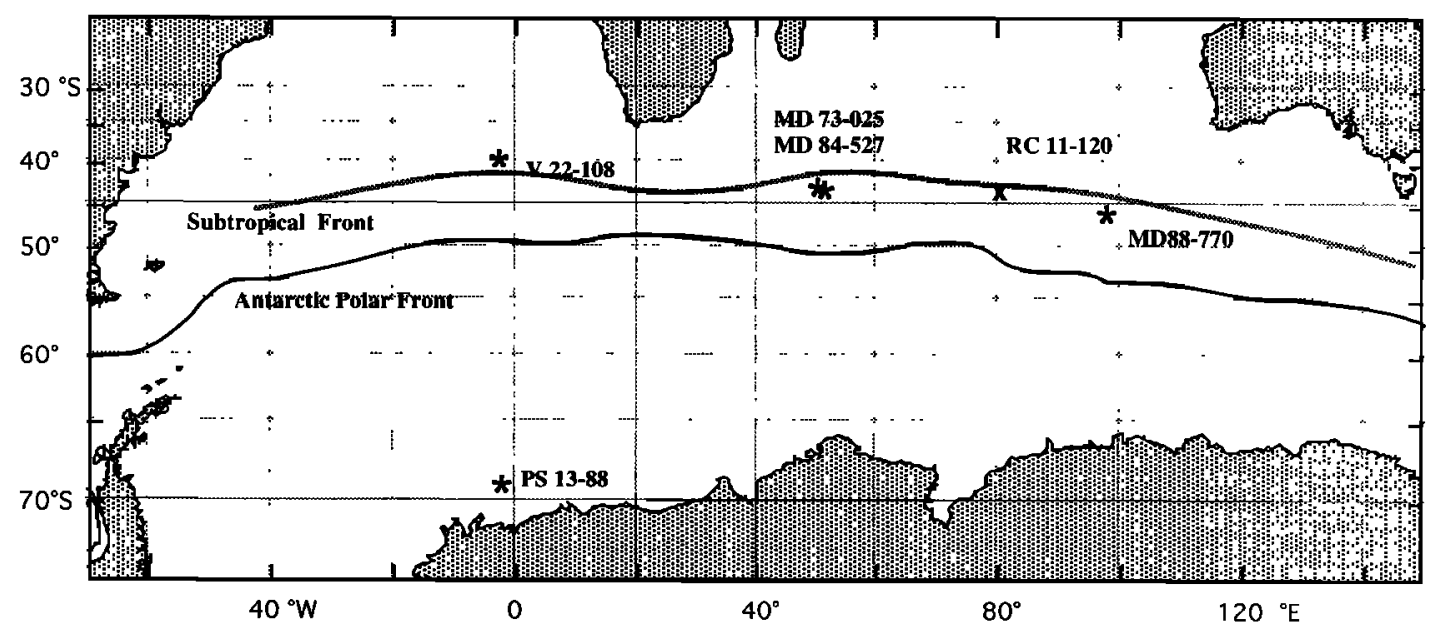

Figure 1. Distribution of published Southern Ocean cores with benthic $\delta^{18} \mathrm{O}$ records covering at least the last $140 \mathrm{kyr}$ with a resolution better than $5 \mathrm{kyr}$ [from Grobe et al., 1990; Labeyrie and Duplessy, 1985; Charles and Fairbanks, 1990; Duplessy et al., 1988]. Core RC 11-120 is added for reference [Martinson et al., 1987]. The main frontal zones are reported from Gordon et al. [1982].

phases are associated with large decreases in salinity. Climatic changes in this area of the Southern Ocean are therefore marked with north-south shifts of the zone between warm, saline, surface tropical waters and cold, low salinity, polar waters. They are probably associated with similar shifts in the westerly wind belt.

This evolution points to a major role of the low-latitude surface water temperatures and atmospheric circulation as an interhemispheric link during glacial-interglacial transitions.

\section{The Isotopic Records of Planktonic and Benthic Foraminifera}

The foraminiferal ${ }^{18} \mathrm{O} /{ }^{16} \mathrm{O}$ and ${ }^{13} \mathrm{C} /{ }^{12} \mathrm{C}$ isotopic ratios (expressed as $\delta^{18} \mathrm{O}$ and $\delta^{13} \mathrm{C}$ versus Pee Dee Belemnite (PDB)) have been measured on an automated carbonate preparation line coupled to a Finnigan MAT 251 mass spectrometer. The mean external reproducibility of powdered carbonate standards is $\pm 0.05 \%$ for oxygen and carbon. Data are reported using as reference NBS19 $\delta^{18} \mathrm{O}$ of $-2.20 \%$ and $\delta^{13} \mathrm{C}$ of $+1.95 \%$ versus PDB [Hut, 1987; Coplen, 1988]. Prior to isotopic analysis, hand-picked foraminifera are cleaned in pure methanol and heated under vacuum at $400^{\circ} \mathrm{C}$.
Both planktonic foraminifera species Globigerina bulloides and Neogloboquadrina pachyderma s. were analysed from the same size fraction $(200-250 \mu \mathrm{m})$. Measured $\delta^{18} \mathrm{O}$ values are similar for both species in sections where they are both abundant (mean difference between $G$. bulloides and $N$. pachyderma s. is $\Delta \delta^{18} \mathrm{O}=0.11 \pm 0.26 \%$ o for these periods). This is not true during major climatic transitions (Table 1). Bard et al. [1987] have shown that benthic bioturbation redistributes a fraction of the shells from depths of high relative abundance to levels above and below. A fraction of the abundant N. pachyderma $\mathrm{s}$. shells from glacial levels are therefore transported (with their "heavy" $\delta^{18} \mathrm{O}$ ) to the adjacent interglacial levels, where this species is less abundant. Conversely, some of the G. bulloides shells with their "light" $\delta^{18} \mathrm{O}$ values, abundant in interglacial levels, are moved to the adjacent glacial levels. This results in shifting the transition between "warm" and "cold" $\delta^{18} \mathrm{O}$ values toward the interglacial for $N$. pachyderma s. and toward glacial for $G$. bulloides. Since the present study concentrates on the timing of climatic changes, this effect must be taken into account. Therefore the mean planktonic $\delta^{18} \mathrm{O}$ signal is built from both $G$. bulloides and $N$. pachyderma s. $\delta^{18} \mathrm{O}$ data sets after rejection of the values corresponding to a low relative abundance (less than 10\%) for the corresponding foraminiferal species.

Table 1. Isotopic Data Versus Depth, Corrected for Specific Fractionation, for the Top $108 \mathrm{~cm}$

\begin{tabular}{|c|c|c|c|c|c|c|c|c|c|c|}
\hline $\begin{array}{c}\text { Depth, } \\
\mathrm{cm}\end{array}$ & $\begin{array}{c}\text { G. bull. } \\
\delta^{18} \mathrm{O}, \% \text { o }\end{array}$ & $\begin{array}{l}\text { N.pach. } \\
\delta^{18} \mathrm{O}, \% o\end{array}$ & $\begin{array}{c}\text { C. wull. } \\
\delta^{18} \mathrm{O}, \% \text { \% }\end{array}$ & $\begin{array}{c}\text { E. exi. } \\
\delta^{18} \mathrm{O}, \% 0\end{array}$ & $\begin{array}{c}\text { M. barl } \\
\delta^{18} \mathrm{O}, \% o\end{array}$ & $\begin{array}{c}\text { benth. } \\
\delta^{18} \mathrm{O}, \% \text { o }\end{array}$ & $\begin{array}{c}C \text { wull. } \\
\delta^{13} \mathrm{C}, \% \text { \% }\end{array}$ & $\begin{array}{c}\text { M. barl } \\
\delta^{13} \mathrm{C}, \% \circ\end{array}$ & $\begin{array}{c}\text { E. ext. } \\
\delta^{17} \mathrm{C}, \% o\end{array}$ & $\begin{array}{c}\text { benth } \\
\delta^{13} \mathrm{C}, \% c\end{array}$ \\
\hline 0 & & $1.84 *$ & 3.48 & 3.45 & 3.31 & 3.41 & 0.17 & 0.28 & 0.07 & 0.17 \\
\hline 2 & 1.81 & - & - & - & - & - & - & & - & - \\
\hline 4 & 1.78 & - & - & - & - & - & - & - & - & - \\
\hline 6 & 2.05 & - & - & - & - & - & - & - & - & - \\
\hline 8 & 1.81 & - & - & - & - & - & - & - & - & - \\
\hline 10 & - & $17^{*}$ & 3.37 & - & - & 3.37 & 0.05 & - & - & 0.05 \\
\hline 12 & 1.69 & - & - & - & - & - & - & - & - & - \\
\hline 14 & 1.91 & - & - & - & - & - & - & - & - & - \\
\hline 16 & 1.9 & - & - & - & - & - & - & - & - & - \\
\hline
\end{tabular}


Table 1. (continued)

\begin{tabular}{|c|c|c|c|c|c|c|c|c|c|c|}
\hline $\begin{array}{l}\text { Depth, } \\
\mathrm{cm}\end{array}$ & $\begin{array}{c}\text { G. bull } \\
\delta^{18} \mathrm{O}, \% c\end{array}$ & $\delta^{18} \mathrm{O}, \%$ & $\begin{array}{c}\text { C. wull. } \\
\delta^{18} \mathrm{O}, \% \circ\end{array}$ & $\begin{array}{c}E . \text { exi. } \\
\delta^{18} \mathrm{O}, \% 0\end{array}$ & $\begin{array}{c}M . \text { barl } \\
\delta^{18} \mathrm{O}, \% o\end{array}$ & $\begin{array}{c}\text { benth. } \\
\delta^{18} \mathrm{O}, \% 0\end{array}$ & $\begin{array}{c}\text { C. wull } \\
\delta^{13} \mathrm{C}, \% c\end{array}$ & $\begin{array}{c}M \text { barl } \\
\delta^{13} \mathrm{C}, \% c\end{array}$ & $\begin{array}{c}\text { E. exi. } \\
\delta^{13} \mathrm{C}, \% c\end{array}$ & $\begin{array}{c}\text { benth } \\
\delta^{13} \mathrm{C}, \% c\end{array}$ \\
\hline 18 & 1.96 & - & - & - & - & - & - & - & - & - \\
\hline 20 & - & $1.67^{*}$ & 3.49 & 3.44 & - & 3.47 & -0.02 & - & 0.08 & 0.03 \\
\hline 22 & 1.67 & - & - & - & - & - & - & - & - & - \\
\hline 24 & 1.77 & - & - & - & - & - & - & - & - & - \\
\hline 26 & 1.81 & - & - & - & - & - & - & - & - & - \\
\hline 28 & 1.58 & - & - & - & - & - & - & - & - & - \\
\hline 30 & - & $172^{*}$ & 3.49 & - & . & 3.49 & 0.12 & - & - & 0.12 \\
\hline 32 & 1.59 & - & - & - & - & - & - & - & - & \\
\hline 40 & - & 1.81 & 3.93 & 3.99 & 3.93 & 3.95 & -0.18 & 0.44 & -0.22 & 0.01 \\
\hline 42 & 1.54 & 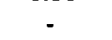 & - & - & - & - & - & - & - & - \\
\hline 44 & 1.98 & - & - & . & - & - & - & . & . & . \\
\hline 46 & 2.08 & - & - & - & - & - & - & - & - & - \\
\hline 48 & 2.35 & - & - & - & - & - & - & - & - & . \\
\hline 50 & - & 2.54 & 4.12 & - & 4.43 & 4.27 & -0.02 & -0.21 & - & -0.12 \\
\hline 52 & 2.77 & - & - & - & - & - & - & - & - & - \\
\hline 54 & 2.43 & - & - & - & - & - & - & - & - & - \\
\hline 56 & 2.51 & - & - & - & - & - & - & - & - & - \\
\hline 58 & 2.44 & - & - & - & - & - & - & . & - & - \\
\hline 60 & . & 2.72 & 4.75 & - & 4.86 & 4.81 & -0.35 & .051 & . & .043 \\
\hline 62 & 2.62 & - & - & - & - & - & - & - & - & - \\
\hline 64 & 2.51 & - & - & - & . & - & - & - & . & . \\
\hline 66 & 2.86 & - & - & - & - & - & - & - & - & - \\
\hline 68 & $2.39 *$ & - & - & - & - & - & - & - & - & - \\
\hline 70 & . & 3.65 & - & - & 5.08 & 5.08 & - & -0.78 & - & -0.78 \\
\hline 72 & $2.76^{*}$ & - & - & - & - & - & - & - & - & - \\
\hline 74 & $2.54 *$ & - & - & - & - & - & - & - & - & - \\
\hline 76 & $2.85^{*}$ & - & - & - & - & - & - & - & - & - \\
\hline 78 & $2.31 *$ & - & - & - & - & - & - & - & - & - \\
\hline 80 & - & 3.94 & - & . & 5.03 & 5.03 & -1.04 & -1.29 & - & -1.17 \\
\hline 82 & $28^{*}$ & - & - & - & - & - & - & - & - & - \\
\hline 84 & $2.86^{*}$ & - & - & . & . & - & - & - & - & - \\
\hline 86 & $2.52 *$ & - & - & - & . & - & - & . & . & - \\
\hline 88 & $2.99 *$ & - & - & - & - & - & - & - & - & - \\
\hline 90 & - & 3.7 & - & - & 5.08 & 5.08 & -1.08 & -1.12 & - & -1.1 \\
\hline 98 & $337^{*}$ & - & - & - & 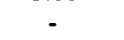 & - &. & . & - & . \\
\hline 100 & - & 4.06 & - & - & 4.86 & 4.86 & & -122 & - & -122 \\
\hline 102 & $3.06^{*}$ & - & - & - & - & - & - & - & - & - \\
\hline 104 & $2.53^{*}$ & - & - & - & - & - & - & - & - & - \\
\hline 106 & $3.26^{*}$ & - & - & - & - & - & - & - & - & - \\
\hline 108 & $3.41^{*}$ & - & - & - & - & - & - & . & - & - \\
\hline
\end{tabular}

The $\delta^{18} \mathrm{O}$ of $G$. bulloides, $N$. pachyderma s., $C$. wuellerstorfi $(+0.64 \%)$, E. exigua $(+0.22 \%), M$ barleeanum $(+0.4 \% \circ)$, and mean benthic values are given, as well as the $\delta^{13} \mathrm{C}$ of $C$. whellerstorfi. $M$. barleeanum $(+0.83 \%)$, E. exigua $(+0.6 \%)$, and mean benthic values.

* Values that are not considered in figures and calculations, because of low foraminiferal abundance.

The benthic $\delta^{18} \mathrm{O}$ record (Figure 2) is based on analysis of the individual species Cibicidoides wuellerstorfi, Melonis barleeanum, and Epistominella exigua; 64 levels were analysed for more than one benthic species. Results are reported with the admitted corrections for specific fractionation: $+0.64 \%$ for $C$. wuellerstorfi and $+0.40 \%$ for $M$. barleeanum [Duplessy et al., 1984]. A correction of $+0.22 \%$ is derived for $E$. exigua from paired measurements of $E$. exigua and $C$. wuellerstorfi (mean difference for the 20 levels sampled during stable paleoclimatic conditions: $+0.42 \pm 0.12 \%$ ). Grobe et al. [1990] propose that this species grows its shell near isotopic equilibrium but do not give specific arguments.

C. wuellerstorfi are mostly absent during glacials and $M$. barleeanum during interglacials. E. exigua was sufficiently abundant to be sampled in the interval between 710 and $970 \mathrm{~cm}$ (end of isotopic stage 5.5 to 4). As for planktonic foraminifera, we did not take keep measurements corresponding to a minimum in relative abundance of a given species.
The mean benthic foraminifera $\delta^{13} \mathrm{C}$ record (Figure 2) is built following the same rules, with corrections derived from paired measurements ( $0 \%$ for $C$. wuellerstorfi, $+0.60 \%$ for $E$. exigua, and $+0.83 \%$ for $M$. barleeanum).

The final foraminiferal $\delta^{18} \mathrm{O}$ and $\delta^{13} \mathrm{C}$ data set is available from $\mathrm{L}$. Labeyrie, and will be transferred to the Boulder World Data Center-A (WDC-A) after publication. A partial example (upper $108 \mathrm{~cm}$ ) is given in Table 1 .

\section{Micropaleontology}

\subsection{Diatoms}

Diatom species distribution has been studied at $5-$ to $10-\mathrm{cm}$ intervals. Changes in sea surface temperature were reconstructed using the diatom transfer function T.F.166/34/4 [Pichon et al., 1987, 1992]. Its construction follows Imbrie and Kipp [1971], except that the relative amounts of diatoms of each of the 34 


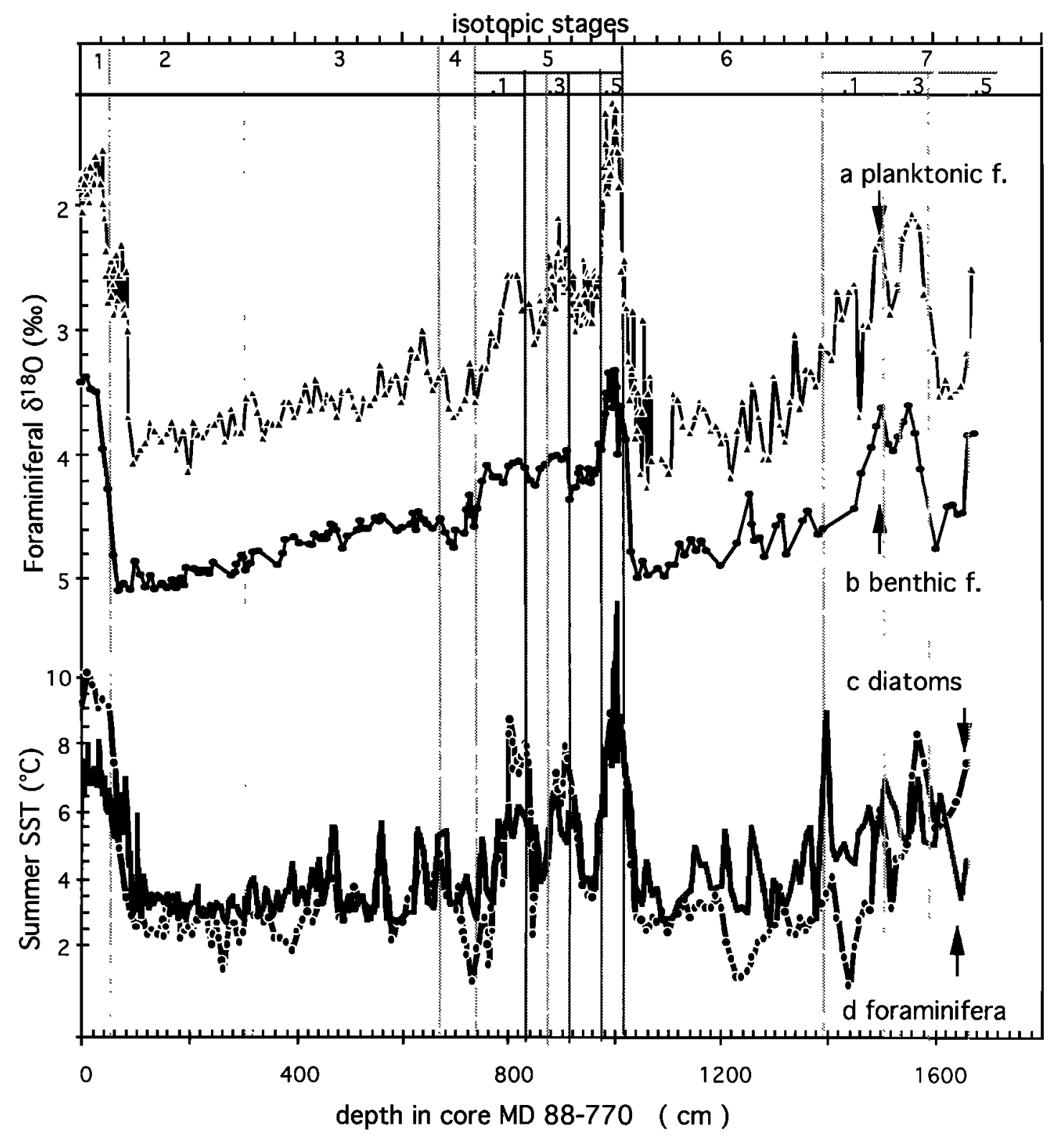

Figure 2. Variations with depth in the core of (a) planktonic foraminiferal $\delta^{18} \mathrm{O}$; (b) benthic foraminiferal $\delta^{18} \mathrm{O}$; (c) summer sea surface temperature (SSST) calculated using the diatom transfer function; (d) SSST estimates using the foraminiferal transfer function. Isotopic stages are defined following Imbrie et al. [1984].

species considered are scaled to the mean relative abundance of that species in the reference database. The scaling is done using four classes of abundance (absent, less than $2 \%$, between $2 \%$ and half of maxımum abundance for that species, more than half of the maximum abundance). This method increases the sensitivity of the transfer function to changes in low abundance species [Pichon et al., 1992] which have well defined temperature tolerance and are thus important for the transfer function. Calibration is done on a set of 124 Holocene and modern core tops. Forty-two samples with assemblages altered by stepwise opal dissolution of five Holocene core tops were added to the natural flora data to take into account the effect of dissolution. The transfer function predicts correct summer surface water temperature in the range -1 to $+12^{\circ} \mathrm{C}$ with a mean standard deviation $(1 \sigma)$ of $\pm 1.1^{\circ} \mathrm{C}$, when tested for modern core tops [Pichon et al., 1987, 1992].

The first three factors of the factor analysis (varimax matrix), which represent $34 \%, 30.2 \%$ and $12.6 \%$, respectively, of the total variance, correspond to three typical biogeographic associations. They group the open ocean species (Thalassiothrix sp., Nitzschia kerguelensis, and the silicoflagellate Distephanus speculum), the ice-related species (Thalassiosira antarctica, Actinocyclus actinochilus, Nitzschia sublineata, Nitzschia cylindrus and Eucampia antarctica) and the Subantarctic species (Thalassionema nitzschioides, Roperia tesselata, Hemidiscus cuneiformis, and the silicoflagellate Dictyocha $s p$.$) , respectively. The fourth factor is directly$ related to the amount of dissolution [Pichon et al., 1992]. In 
core MD 88-770, the ice-related factor represents only a small part of the variance, even during cold periods. This suggests that the core was always between the subtropical and polar fronts. However, summer sea surface temperature estimates during glacials, around $+2^{\circ} \mathrm{C}$, do indicate that the polar front was not far south during these periods.

\subsection{Planktonic Foraminifera}

The foraminiferal species distribution has been established at 5- to $10-\mathrm{cm}$ intervals along the core and at higher resolution for the upper $4 \mathrm{~m}$ (2-cm intervals). Construction of the transfer function follows also Imbrie and Kipp [1971]. It is built on the modern reference database of Prell [1985], with an extended core top reference at high southern latitudes [Labracherie et al., 1989]. SSST temperatures are interpolated from Levitus's Atlas mean February to April 0- to 10-m water temperatures [Levitus, 1982]. The foraminiferal transfer function, when tested on individual core tops against the modem reference database, gives SSST estimates between 0.7 and $23^{\circ} \mathrm{C}$ with a $\sigma=1.1^{\circ} \mathrm{C}$. However, the precision is much poorer in the SSST range -1 to $+3^{\circ} \mathrm{C}$ than above, as the foraminiferal population is then essentially monospecific $N$. pachyderma s. Details of the micropalaeontological study will be discussed in a paper in preparation by $M$. Labracherie et al. (manuscript in preparation, 1995).

The foraminiferal population varies between two characteristic assemblages in the core: the first, which corresponds to the warm periods, is typical of subpolar waters (with $G$. bulloides and $G$. inflata); the second, during the cold periods, is composed of the quasi-monospecific $N$. pachyderma s. population (which corresponds to a maximum SSST value of $+3^{\circ} \mathrm{C}$ ). Such an evolution is in agreement with the results of the diatom study. Results of both transfer functions (Figure 2) will be available from $M$. Labracherie and deposited at the Boulder World Data Center-A after publication. A partial example of the data is reported as Table 2 .

\subsection{Discussion of the Micropalaeontological \\ Results}

Both transfer functions give similar signals. The only significant differences are for the low- and high-temperature extrema.

Let us consider first the interglacial periods. During the Holocene (the top $100 \mathrm{~cm}$ ) and the warm interstadials of isotopic stages 5.1 and 5.3 (about 800 and $900 \mathrm{~cm}$ respectively), the diatom transfer function gives SSST (Figure $2 \mathrm{c})$ about $2^{\circ} \mathrm{C}$ higher than the foraminiferal SSST (Figure 2d), i.e., $+9-10^{\circ} \mathrm{C}$ versus $+7-8^{\circ} \mathrm{C}$. The modern SSST given by Levitus [1982] at the core location is $+9^{\circ} \mathrm{C}$. The foraminiferal estimate appears therefore systematically too cold by about $1^{\circ} \mathrm{C}$ and the diatom estimate too warm by that amount for the core top. At the opposite, during the peak interglacial of stage 5.5 (about $1000 \mathrm{~cm}$ ), SSST are higher for foraminifera $\left(10.5^{\circ} \mathrm{C}\right.$ versus $8.5^{\circ} \mathrm{C}$ for diatoms). The peak warmth, at $1004 \mathrm{~cm}$ $\left(+13^{\circ} \mathrm{C}\right.$, foraminiferal SSST), has not been sampled for diatoms but would fall out of the calibration range of the diatom transfer function. Core RC $11-120$, located $2^{\circ} 30^{\circ}$ further north, in subtropical waters (Figure 1), yields SSST estimates of $+11.2^{\circ} \mathrm{C}$ for Holocene and $+13.5^{\circ} \mathrm{C}$ for the 5.5 interglacial (Spectral Mapping (SPECMAP) file, WDC-A database). These values are compatible with both sets of values for core MD 88-770, taking into account the latitudinal difference.
We do not have ready explanations for the observed differences between diatom and foraminiferal transfer functions. They appear systematic within each climatic period. They may derive from changes in the upper water structure and seasonality of the productivity or from a contribution of shells transported by the circumpolar currents from more southerly or northerly environments. In the latter case, the diatom transfer function would be much more affected than the foraminifera transfer function, as it is more sensitive to relative changes in low abundance species. During cold periods, diatoms give mean SSST values about $1^{\circ} \mathrm{C}$ colder than foraminifera. The difference exceeds $2^{\circ}-3^{\circ} \mathrm{C}$ during the maximum cold events of stages 2,4 , and 6. Such a difference may be expected. As opposed to foraminifera, diatoms are far from their minimum temperature range and will grow even during the colder years. Contrary to foraminifera, they have a high species diversity, and the diatom transfer function is well validated to $-1^{\circ} \mathrm{C}$ SSST. In conclusion, records obtained from diatom and foraminiferal transfer functions are not completely equivalent. The foraminiferal transfer function appears better adapted to record the evolution of the subtropical front in relation with the foraminiferal isotopic record. It has no meanings for SSST below approximatively $+3^{\circ} \mathrm{C}$. The diatom transfer function presents a specific interest for the low-temperature range (polar waters) and for recording sea ice and related hydrology.

Another feature of the records is the apparent lead of foraminifera versus diatom, particularly evident in the early part for the last deglaciation. This point will be considered in the discussion.

\section{Data Analysis and Discussion}

\subsection{Chronostratigraphy of MD 88.770}

The different isotopic stages 1 to 7 may be easily recognised in the isotopic records. However, it is evident from Figure 2 that sedimentation rates were significantly higher during glacial periods. Chronology for the paleoceanographic records from core MD 88-770 was developed in the following steps.

First, accelerator mass spectrometry (AMS) ${ }^{14} \mathrm{C}$ dating of $N$. pachyderma s. was used to build a preliminary timescale for the upper $500 \mathrm{~cm}$. Dating followed the standard procedures at Centre des Faibles Radioactivités (CFR), Gif sur Yvette, with sampling limited to peaks in relative abundance of the considered species. This minimises the effect of bioturbation. Two levels present anomalous young ages (554 and $418 \mathrm{~cm}$ depth). We suspect contamination during cleaning. These levels were excluded from the construction of the timescale. AMS ${ }^{14} \mathrm{C}$ ages are reported (Table 3 and Figure 3) after correction by 480 years, the adopted mean reservoir age [Bard et al., 1990] We did not adjust the reservoir corrected ages to get calendar ages, as proposed by Bard et al. [1993]. The present calibration of the ${ }^{14} \mathrm{C}$ scale is far from being accurate for ages older that $11 \mathrm{kyr}$ B.P. [Bard et al., 1993].

Second, the benthic foraminiferal $\delta^{18} \mathrm{O}$ record of the lower $1170 \mathrm{~cm}$ was graphically correlated with the benthic record of equatorial Pacific core V19-30 [Shackleton and Pisias, 1985], using the Analyseries software developed at CFR (D. Paillard et al., CFR internal report, 1993). We chose the benthic foraminiferal $\delta^{18} O$ record of core V19-30 as SPECMAP reference for its close similarity even for small details with the MD 88-770 $\delta^{18} \mathrm{O}$ 
Table 2. Micropaleontological Data Versus Depth in the Core for the Top $94 \mathrm{~cm}$ and Derived Summer Sea Surface Temperature (SSST) Following Imbrie and Kipp [1971]

\begin{tabular}{|c|c|c|c|c|c|c|c|c|c|}
\hline \multirow[b]{2}{*}{ Depth, cm } & \multicolumn{5}{|c|}{ Diatoms } & \multicolumn{4}{|c|}{ Foraminıfera } \\
\hline & Open Ocean & Ice Zone & Subantarctic & Com. & SSST, ${ }^{\circ} \mathrm{C}$ & pach.s., \% & bull.. \% & Com & SSST, ${ }^{\circ} \mathrm{C}$ \\
\hline 0 & 0.49 & 0.13 & 0.76 & 0.85 & 9.5 & 16 & 40 & 0.99 & 7.8 \\
\hline 2 & - & - & - & - & - & 16 & 48 & 100 & 7.0 \\
\hline 4 & - & - & - & - & - & 13 & 52 & 099 & 78 \\
\hline 6 & - & - & - & - & - & 15 & 50 & 1.00 & 73 \\
\hline 8 & - & - & - & - & - & 12 & 50 & 100 & 78 \\
\hline 10 & & 0.09 & 0.77 & 0.83 & 10.5 & 17 & 44 & 099 & 71 \\
\hline 12 & - & - & - & - & - & 12 & 48 & 100 & 7.9 \\
\hline 14 & - & - & - & - & - & 15 & 45 & 0.98 & 7.5 \\
\hline 16 & - & - & - & - & - & 16 & 44 & 099 & 74 \\
\hline 18 & - & - & - & - & - & 21 & 42 & 099 & 7.1 \\
\hline 20 & 0.44 & 0.12 & 0.78 & 0.85 & 10.3 & 19 & 40 & 098 & 73 \\
\hline 22 & - & - & - & - & - & 15 & 43 & 0.98 & 76 \\
\hline 24 & - & - & - & - & - & 16 & 46 & 100 & 71 \\
\hline 26 & - & - & - & - & - & 17 & 48 & 0.99 & 71 \\
\hline 28 & - & - & - & - & - & 13 & 49 & 0.99 & 75 \\
\hline 30 & 0.53 & 0.14 & 0.73 & 0.86 & 9.0 & 9 & 56 & 1.00 & 87 \\
\hline 32 & - & - & . & - & - & 13 & 53 & 099 & 7.8 \\
\hline 34 & - & - & - & - & - & 14 & 50 & 0.99 & 74 \\
\hline 36 & - & - & - & - & - & 18 & 42 & 0.99 & 7.4 \\
\hline 38 & - & - & - & - & - & 14 & 51 & 0.99 & 73 \\
\hline 40 & 0.54 & 0.13 & 0.71 & 0.89 & 9.2 & 16 & 48 & 099 & 7.1 \\
\hline 42 & - & - & - & - & - & 13 & 45 & 0.98 & 7.5 \\
\hline 44 & - & - & - & - & - & 16 & 45 & 0.98 & 7.4 \\
\hline 46 & - & - & - & - & - & 19 & 46 & 0.99 & 68 \\
\hline 48 & - & - & - & - & - & 21 & 45 & 099 & 69 \\
\hline 50 & 0.49 & 0.09 & 0.72 & 0.82 & 10.3 & 14 & 53 & 0.99 & 7.8 \\
\hline 52 & - & - & - & - & - & 18 & 50 & 0.99 & 70 \\
\hline 54 & - & - & - & - & - & 20 & 55 & 099 & 72 \\
\hline 56 & - & - & - & - & - & 20 & 52 & 097 & 7.5 \\
\hline 58 & - & - & - & - & - & 19 & 51 & 0.98 & 72 \\
\hline 60 & 051 & 0.26 & 0.68 & 0.79 & 7.0 & 21 & si & 0.98 & 7.0 \\
\hline 62 & - & - & - & - & - & 26 & 50 & 0.99 & 6.6 \\
\hline 64 & - & - & - & - & - & 21 & 53 & 0.99 & 69 \\
\hline 66 & - & - & - & - & - & 21 & 49 & 0.97 & 72 \\
\hline 68 & - & - & - & - & - & 16 & 56 & 098 & 77 \\
\hline 70 & 0.66 & 0.26 & 0.46 & 0.74 & 5.1 & 22 & 56 & 0.98 & 7.0 \\
\hline 72 & - & - & - & - & - & 23 & 51 & 099 & 67 \\
\hline 74 & - & - & - & - & - & 23 & 40 & 0.94 & 7.5 \\
\hline 76 & - & - & - & - & - & 40 & 34 & 0.97 & 72 \\
\hline 78 & - & - & - & - & - & 54 & 27 & 100 & 64 \\
\hline 80 & 0.72 & 0.32 & 0.29 & 0.72 & 3.1 & 33 & 43 & 0.99 & 6.7 \\
\hline 82 & - & - & - & - & - & 44 & 30 & 099 & 7.2 \\
\hline 84 & - & - & - & - & - & 33 & 40 & 0.99 & 6.7 \\
\hline 86 & - & - & - & - & - & 40 & 38 & 0.99 & 69 \\
\hline 88 & - & - & - & - & - & 75 & 14 & 100 & 44 \\
\hline 90 & 0.72 & 0.35 & 0.32 & 0.76 & 2.8 & 30 & 49 & 098 & 68 \\
\hline 92 & - & - & - & - & - & 82 & 10 & 100 & 39 \\
\hline 94 & - & - & - & - & - & 92 & 4 & 1.00 & 31 \\
\hline
\end{tabular}

Results of the factor analysis of the diatom population were derıved following Pichon et al. [1992]. The relative weight of the Open Ocean, Ice Zone, and Subantarctic diatom associations, their communality (Com.) and the calculated Summer Sea surface temperatures (SSSST) are given, as well as the relative abundance of the planktonic foramınıfera $N$. pachyderma s (polar factor) (pach.s), and G. bulloides (transitional factor) (bull.), their communality, and SSST, calculared by the foraminiferal transfer function.

record (Figure 3). This helped to accurately define the times of rapid change in sedimentation rate. V19-30 has been used in the "short stack" benthic record of Pisias et al. [1984] and is defined in the temporal SPECMAP framework of Martinson et al. [1987].

Finally, the timescale derived from the two first steps was further modified using Martinson et al.'s inverse correlation technique (still with the benthic record of V19-30) [Martinson et al., 1982]. This step improves coherency in the cross correlation between the MD 88-770 isotopic record and insolation and puts the corresponding palaeoenvironmental changes within the SPECMAP temporal framework [Imbrie et al., 1992, 1993]. The poor control at both ends of the record introduces a mean shift of $+0.7 \mathrm{kyr}( \pm 1 \mathrm{kyr}$ at $1 \sigma$ ) when compared to the graphically derived timescale. The effect is particularly apparent for the upper $600 \mathrm{~cm}$ (the last $50 \mathrm{kyr}$ ) and the 
Table 3. Results of the Accelerator Mass Spectrometry ${ }^{14} \mathrm{C}$ dating of $N$. pachyderma s.

\begin{tabular}{cccc}
\hline Depth, cm & Age, ka & Corrected Ages & Error at 1 Sigma \\
\hline 20 & 6.18 & 5.70 & 0.10 \\
46 & 1148 & 1100 & 012 \\
58 & 1263 & 12.15 & \\
68 & 12.01 & 11.53 & 0.15 \\
74 & 13.98 & 1350 & 0.15 \\
114 & 1726 & 16.78 & 022 \\
228 & 22.09 & 2161 & 0.30 \\
256 & 2088 & 2040 & 0.26 \\
278 & 21.77 & 2129 & 0.29 \\
304 & 2564 & 25.16 & 039 \\
342 & 25.49 & 25.01 & 0.45 \\
360 & 27.86 & 27.38 & 0.51 \\
384 & 30.98 & 30.50 & 0.67 \\
436 & 33.27 & 3279 & 0.82 \\
472 & 37.70 & 37.22 & 1.50 \\
524 & 45.10 & 44.62 & 3.30 \\
$418 *$ & 27.31 & 26.83 & 0.51 \\
$554^{*}$ & 37.20 & 3672 & 130 \\
\hline
\end{tabular}

* values rejected

transition from 1sotopic stages 6 to 5.5 , where ages increase by 1.5 to $2 \mathrm{kyr}$. This brings the calculated ages for the $11-40 \mathrm{ka}$ period close to what would have been estimated using the correction for calendar ages [Bard et al., 1993]. The global correlation coefficient of the dated benthic records is 0.96 between MD 88-770 and V19-30 (Figure 3) and 0.91 between MD 88-770 and the SPECMAP short stack, respectively. Final depth/age results for the upper $416 \mathrm{~cm}$ are reported in Table 4 for example. This data will also be available from the Boulder World Data Center -A.

\subsection{Evolution Over the Last $230 \mathrm{kyr}$}

The different records are reported versus age in the core in Figure 4. As discussed previously, the SSST estimated by the foraminiferal transfer function is considered to better represent the overall variability of surface waters than the SST estimated by the diatom transfer function, although it does not record temperature excursions below $3^{\circ} \mathrm{C}$ (Figure 4a). SSST presents a rapıd variability for both glacials and interglacials approxımatively in phase with the planktonic foraminiferal $\delta^{18} \mathrm{O}$ record (Figure 4b). The latter signal records the effects of both the changes in SSST and ocean water $\delta^{18} O$. The largest difference between SSST and planktonic $\delta^{18} \mathrm{O}$ signals occurs during isotopic stage 5.5, where the second light $\delta^{18} \mathrm{O}$ peak is not paralleled by a SSST increase. The benthic foraminiferal $\delta^{18} \mathrm{O}$ signal (Figure $4 c$ ) records the continental ice sheets waxing and waning but also the effect of deep water temperature changes [Shackleton, 1967; Labeyrie et al., 1987]. A lead of SSST and planktonic foraminiferal $\delta^{18} \mathrm{O}$ over benthic $\delta^{18} \mathrm{O}$ appears during each cooling phase. The benthic foraminiferal $\delta^{13} \mathrm{C}$ record (Figure 4d), although rather noisy, shows strong analogies with the benthic $\delta^{18} \mathrm{O}$ record. As for other Southern Ocean cores [Duplessy et al., 1988; Curry et al., 1988; Charles and Fairbanks, 1992], exceptionally light $\delta^{13} \mathrm{C}$ values are observed during glacial periods, compared to records from the other oceanic basins. The interpretation of that signal is still a matter of debate, but there are strong indications that, as in the modem ocean, light $\delta^{17} \mathrm{C}$ values record accumulation of ${ }^{17} \mathrm{C}$ poor dissolved $\mathrm{CO}_{2}$ (produced by oxidation of settling organic matter) in the deep southern waters following the isolation of this water mass during glactal periods [Michel et al., 1995, and references therein]. Whatever the precise origin of that signal, we may safely admit that a return, even partial, to the modern thermohaline circulation, with ventilation of the deep Southern Ocean by NADW and/or Antarctic Bottom Water (AABW), will shift the benthic foraminiferal $\delta^{17} \mathrm{C}$ to values closer to those of the deep Pacific and North Atlantic records [Charles and Fairbanks, 1992]. In that respect, information carried by the benthic foraminiferal $\delta^{18} \mathrm{O}$ and $\delta^{13} \mathrm{C}$ is different: $\delta^{18} \mathrm{O}$ tracks the northern ice sheets and their influence on NADW; $\delta^{17} \mathrm{C}$ tracks the isolation of Southern Ocean deep waters.

\subsection{Study in the Spectral Domain}

Spectral analysis of the climatic response to the insolation forcing may help to clarify the relationships between Southern Ocean climatic records of core MD 88-770 and global climate. Imbrie et al. [1992, 1993] have shown that the periodic component of paleoclimatic proxies variability may be considered as a sum of three independent elements, the response to precession $\left(\approx 1 / 21 \mathrm{kyr}^{-1}\right)$, obliquity $\left(\approx 1 / 43 \mathrm{kyr}^{-1}\right)$, and continental ice volume (which contributes largely to the $1 / 100 \mathrm{kyr}^{-1}$ frequency band). This third parameter is probably itself a nonlinear response to precession, obliquity, eccentricity, and their harmonics. However, seen from the Southern Ocean, we may consider the continental northern ice sheets as an external forcing acting primarily in the $1 / 100 \mathrm{kyr}^{-1}$ band. Paleoclımatic response to insolation appears linear in the precession and obliquity bands [Imbrie et al., 1992, 1993, and references therein], but both bands carry different information. McIntyre et al. [1989], among others, have shown that low-latitude paleoclimatic responses (sea surface temperature, equatorial upwelling) have a major part of their variability in the precession band. At the opposite, proxies which record processes linked with high-latitude climatology (benthic foraminifera $\delta^{18} \mathrm{O}$ and $\delta^{13} \mathrm{C}, \mathrm{Cd} / \mathrm{Ca}$, lysocline depth) have most of their variance in the $1 / 100$ - and $1 / 41-\mathrm{kyr}^{-1}$ bands [Imbrie et al., 1992, 1993, and references therein].

Each of the climatic bands has its own properties when considering interhemispheric relationship:

The first is the $1 / 100-\mathrm{kyr}^{-1}$ "ice forcing" band. Most of the continental glacial-interglacial ice volume changes occur in the northern hemisphere [CLIMAP, 1981]. Since purely lowlatitude paleoclimatic proxies do not exhibit strong variability in the $1 / 100 \mathrm{kyr}^{-1}$ band [Mclntyre et al., 1989], ice sheet forcing on southern latitudes acts probably through a modulation of the deep water dynamic and chemistry and its resulting effect on heat transfer and atmospheric $\mathrm{pCO}_{2}$.

The second is the $1 / 43 \mathrm{kyr}^{-1}$ "obliquity" band. This parameter modulates the distribution of solar energy between low and high latitudes synchronously over both hemispheres.

The third is the $1 / 21 \mathrm{kyr}^{-1}$ "precession" band. Insolation is modulated by the relative positions of perihelion and summer solstice. It is in opposition of phase for both hemispheres. This is the major band where interhemispheric transfer processes through atmosphere and surface oceans should play a significant role. 


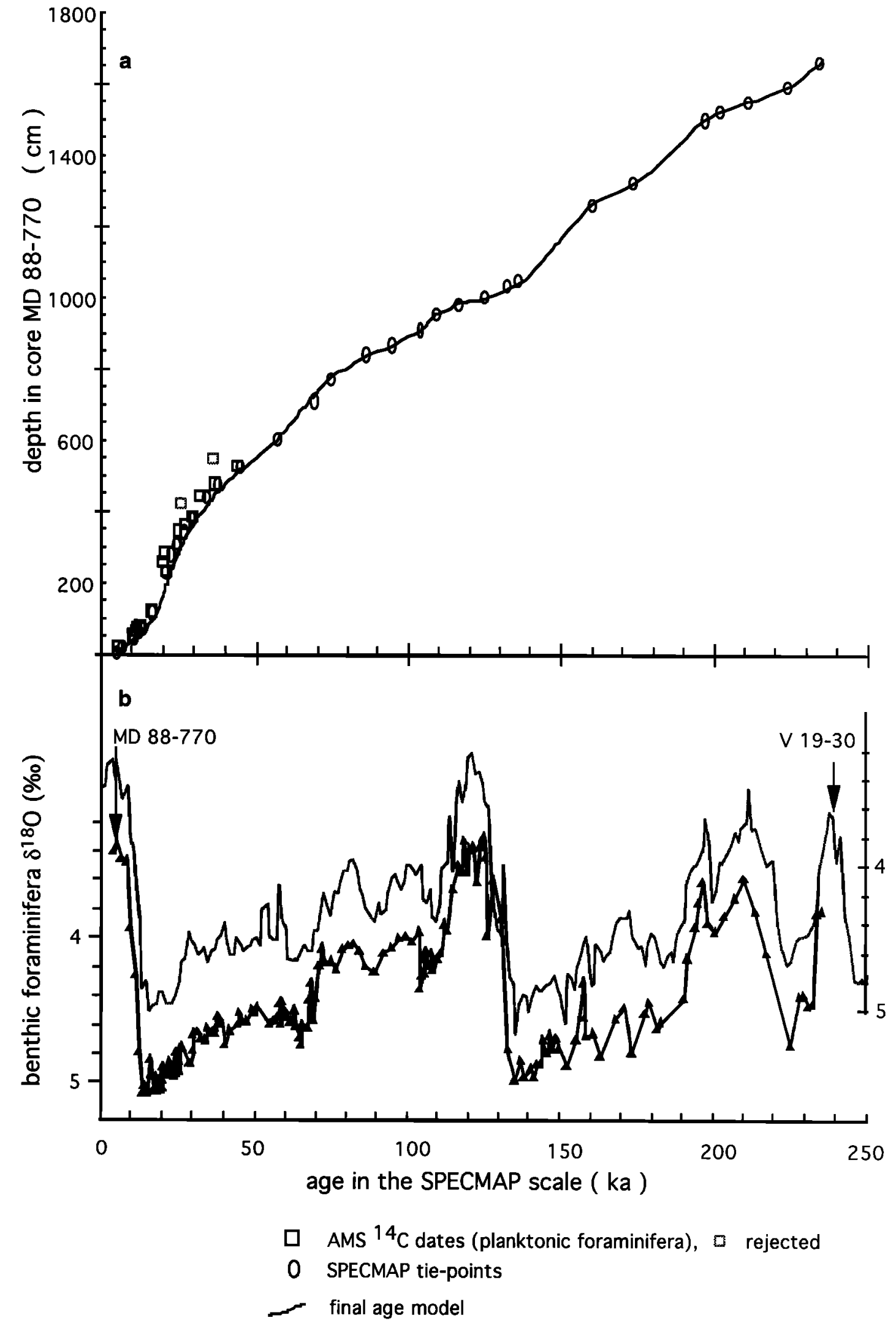

Figure 3. Construction of the timescale: (a) Age-depth relationship, with accelerator mass spectrometry (AMS) ${ }^{14} \mathrm{C}$ dates, tie points derived from the graphical correlation of MD 88-770 and $\mathrm{V} \mathrm{19-30}$ benthic foraminiferal $\delta^{18} \mathrm{O}$ records, and the final inverse correlation using Martinson et al. [1982] method; (b) The benthic foraminiferal $\delta^{18} \mathrm{O}$ records of cores MD 88-770 and V 19-30 after the final correlation. 
Table 4. Depth versus Age Scale for the upper $416 \mathrm{~cm}$ of Core MD 88-770

\begin{tabular}{|c|c|c|c|c|c|c|c|}
\hline Depth, cm & ka & Depth, cm & ka & Depth, cm & $\mathbf{k a}$ & Depth, cm & ka \\
\hline 0 & 4.59 & 104 & 17.23 & 208 & 21.62 & 312 & 26.46 \\
\hline 2 & 4.87 & 106 & 17.39 & 210 & 21.69 & 314 & 2658 \\
\hline 4 & 5.16 & 108 & 1755 & 212 & 21.77 & 316 & 26.70 \\
\hline 6 & 5.44 & 110 & 17.70 & 214 & 21.84 & 318 & 2683 \\
\hline 8 & 5.72 & 112 & 17.86 & 216 & 21.92 & 320 & 26.95 \\
\hline 10 & 6.00 & 114 & 18.02 & 218 & 21.99 & 322 & 27.08 \\
\hline 12 & 6.28 & 116 & 18.10 & 220 & 22.07 & 324 & 27.20 \\
\hline 14 & 6.57 & 118 & 18.17 & 222 & 22.15 & 326 & 27.32 \\
\hline 16 & 6.85 & 120 & 18.25 & 224 & 22.22 & 328 & 27.45 \\
\hline 18 & 7.13 & 122 & 18.33 & 226 & 22.29 & 330 & 27.57 \\
\hline 20 & 7.41 & 124 & 18.41 & 228 & 22.38 & 332 & 27.69 \\
\hline 22 & 7.71 & 126 & 18.49 & 230 & 22.46 & 334 & 2781 \\
\hline 24 & 8.02 & 128 & 18.56 & 232 & 22.55 & 336 & 27.93 \\
\hline 26 & 8.32 & 130 & 1864 & 234 & 22.63 & 338 & 2806 \\
\hline 28 & 8.62 & 132 & 18.72 & 236 & 22.72 & 340 & 28.18 \\
\hline 30 & 8.92 & 134 & 18.80 & 238 & 22.81 & 342 & 28.31 \\
\hline 32 & 9.22 & 136 & 18.88 & 240 & 22.90 & 344 & 28.44 \\
\hline 34 & 9.52 & 138 & 18.95 & 242 & 22.99 & 346 & 28.58 \\
\hline 36 & 9.82 & 140 & 19.03 & 244 & 23.08 & 348 & 28.73 \\
\hline 38 & 10.12 & 142 & 19.11 & 246 & 23.17 & 350 & 28.87 \\
\hline 40 & 10.42 & 144 & 19.18 & 248 & 23.25 & 352 & 29.01 \\
\hline 42 & 10.72 & 146 & 1926 & 250 & 2334 & 354 & 29.15 \\
\hline 44 & 11.02 & 148 & 19.33 & 252 & 23.43 & 356 & 29.29 \\
\hline 46 & 11.31 & 150 & 19.41 & 254 & 23.52 & 358 & 29.44 \\
\hline 48 & 11.61 & 152 & 19.49 & 256 & $\begin{array}{l}23.32 \\
23.61\end{array}$ & 360 & 29.58 \\
\hline 50 & 11.91 & 154 & 19.56 & 258 & 23.69 & 362 & 29.73 \\
\hline 52 & 12.20 & 156 & 19.64 & 260 & 23.78 & 364 & 29.87 \\
\hline 54 & 12.50 & 158 & 19.72 & 262 & 23.87 & 366 & 30.01 \\
\hline 56 & 12.79 & 160 & 19.79 & 264 & 23.96 & 368 & 30.15 \\
\hline 58 & 13.08 & 162 & 19.87 & 266 & 24.05 & 370 & 30.29 \\
\hline 60 & 13.33 & 164 & 19.95 & 268 & 24.13 & 372 & 30.43 \\
\hline 62 & 13.58 & 166 & 20.02 & 270 & 24.22 & 374 & 30.57 \\
\hline 64 & 13.83 & 168 & 20.10 & 272 & $\begin{array}{l}24.22 \\
24.31\end{array}$ & 376 & 30.72 \\
\hline 66 & 14.07 & 170 & 20.18 & 274 & $\begin{array}{l}24.31 \\
24.40\end{array}$ & 378 & 30.86 \\
\hline 68 & 14.32 & 172 & 20.26 & $\begin{array}{l}274 \\
276\end{array}$ & $\begin{array}{l}24.40 \\
24.49\end{array}$ & 380 & 31.00 \\
\hline 70 & 14.48 & 174 & 20.33 & 278 & 24.59 & 382 & 31.14 \\
\hline 72 & 14.64 & 176 & 20.41 & 280 & 24.68 & 384 & 31.28 \\
\hline 74 & 14.81 & 178 & 20.48 & 282 & $\begin{array}{l}24.68 \\
24.79\end{array}$ & 386 & 31.45 \\
\hline 76 & 14.97 & 180 & 20.56 & 284 & $\begin{array}{l}24.79 \\
24.90\end{array}$ & 388 & 31.62 \\
\hline 78 & 15.13 & 182 & 20.64 & 286 & $\begin{array}{l}24.90 \\
25.01\end{array}$ & 390 & 31.79 \\
\hline 80 & 15.30 & 184 & 20.71 & 288 & $\begin{array}{l}25.01 \\
25.11\end{array}$ & 392 & 31.96 \\
\hline 82 & 15.46 & 186 & 20.79 & 290 & 25.22 & $\begin{array}{l}394 \\
396\end{array}$ & $\begin{array}{l}32.13 \\
32.30\end{array}$ \\
\hline 84 & 15.62 & 188 & 20.86 & 292 & 25.33 & 398 & 32.47 \\
\hline 86 & 15.78 & 190 & 20.94 & 294 & 25.43 & 400 & 32.64 \\
\hline 88 & 15.94 & 192 & 21.02 & 296 & 25.54 & 402 & 32.81 \\
\hline 90 & 16.11 & 194 & 21.09 & 298 & 25.64 & 404 & 32.98 \\
\hline 92 & 16.27 & 196 & 21.16 & 300 & 25.75 & 406 & 33.14 \\
\hline 94 & 16.43 & 198 & 21.24 & 302 & 25.86 & 408 & 33.31 \\
\hline 96 & 16.59 & 200 & 21.31 & 304 & 25.97 & 410 & 33.48 \\
\hline 98 & 16.75 & 202 & 21.39 & 306 & 26.09 & 412 & 33.65 \\
\hline 100 & 16.91 & 204 & 21.47 & 308 & 26.22 & 414 & 33.82 \\
\hline 102 & 17.07 & 206 & 21.54 & 310 & 26.34 & 416 & 33.99 \\
\hline
\end{tabular}

In order to perform spectral analysis, foraminiferal isotopic and SST temporal records (Figure 4) were interpolated at a 0.5 -kyr interval between 4.5 and $235.5 \mathrm{ka}$. Spectral analysis was done by the Blackman-Tukey method [Jenkins and Watts, 1968] using the software Analyseries. The Blakman-Tukey spectral analysis algorithm is derived from the one used in Brown University within the SPECMAP program [Imbrie, 1985; Imbrie et al., 1989]. The analysis is performed with a Barlett-type window, (220 lags and a $0.024 \mathrm{kyr}^{-1}$ bandwidth). For easier intercomparison of the different parameters, variance powers are normalised by the integrated variance over the studied frequency range ( 0 to $0.1 \mathrm{kyr}^{-1}$ ). They are therefore presented as relative variance powers. The five studied parameters, i.e., SSST (diatom and foraminifera), foraminiferal $\delta^{18} \mathrm{O}$ (benthic and planktonic), and $\delta^{13} \mathrm{C}$ (benthic) present the same general spectral responses (Figure 5), with variance maxima around $1 / 106 \mathrm{kyr}^{-1}, 1 / 43 \mathrm{kyr}^{-1}, 1 / 23 \mathrm{kyr}^{-1}$, and $1 / 19$ $\mathrm{kyr}^{-1}$. Additional high-frequency harmonic responses around $1 / 13.5$ and $1 / 10 \mathrm{kyr}^{-1}$, which represent less than $2 \%$ of the integrated variance, are not reported. In the following discussion, considerations about the $1 / 100-\mathrm{kyr}^{-1}$ band should be considered as semiquantitative. The $240-\mathrm{kyr}$ record is too short for results to be fully reliable in that frequency band. 


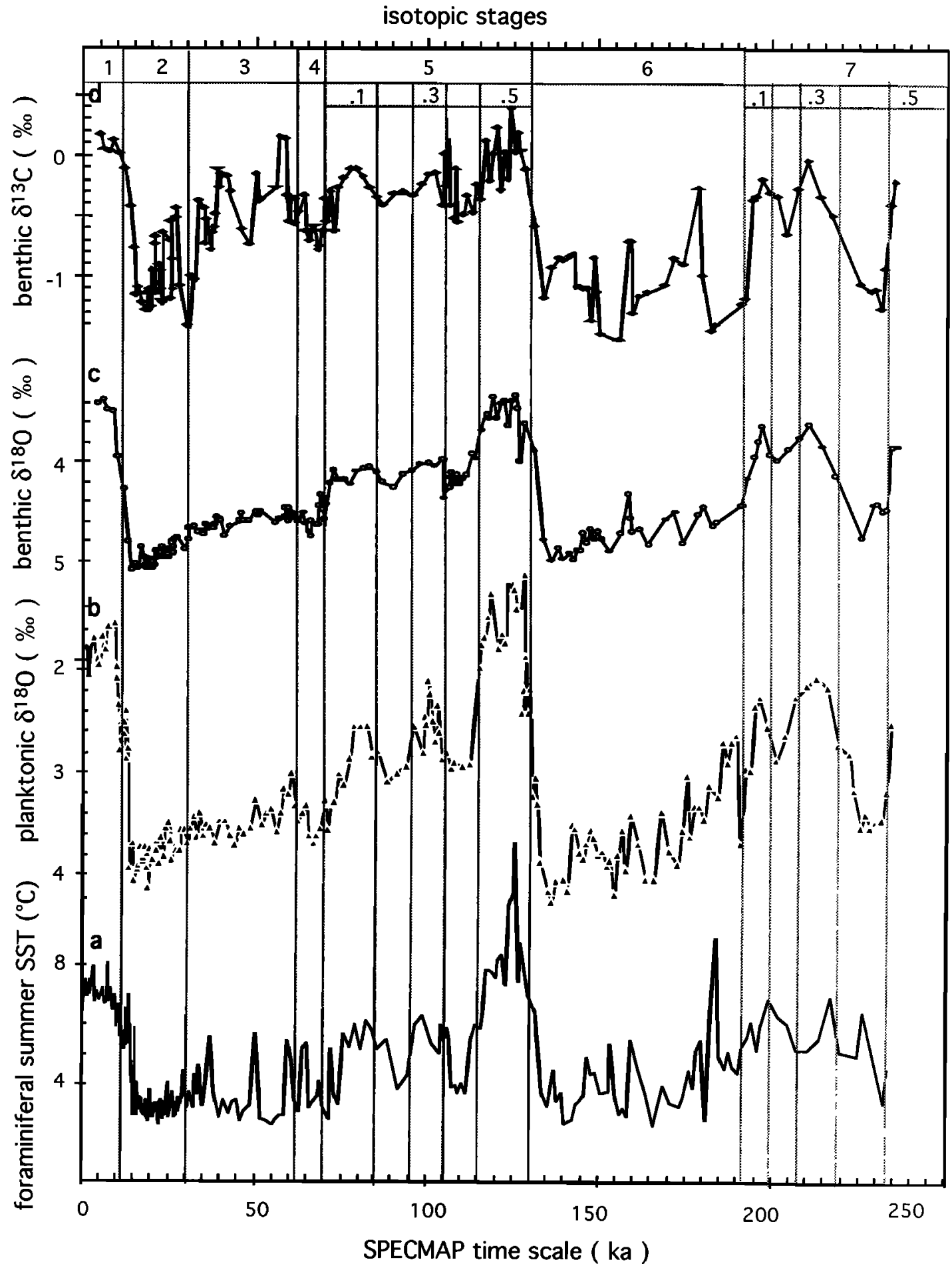

Figure 4. Paleoproxies from core MD 88-770 versus age (ka): (a) summer sea surface temperature (SSST) using the foraminiferal transfer function; (b) planktonic foraminiferal $\delta^{18} \mathrm{O}$; (c) benthic foraminiferal $\delta^{18} \mathrm{O}$; (d) benthic foraminiferal $\delta^{13} \mathrm{C}$.

Following Imbrie et al. [1992], cross correlations (Blackman-Tukey) are calculated between the different Southern Ocean climatic proxies, the benthic $\delta^{18} \mathrm{O}$, and the northern hemisphere insolation (June 15 at $65^{\circ} \mathrm{N}$ ) records for the three major bands of the climatic response at $1 / 106,1 / 43$, and $1 / 23$ kyr $^{-1}$ (Figure 5 and Table 5). Covariances with the benthic $\delta^{18} \mathrm{O}$ record are highly significant $(0.75<\mathrm{Coh}<0.99)$ for the three bands and all the proxies ( $80 \%$ confidence interval for arctanh $($ Coh $)= \pm 0.52$ [Jenkins and Watts, 1968]). Covariance between the different Southern Ocean proxies is not significant for the $1 / 106 \mathrm{kyr}^{-1}$ band $(0.23<\mathrm{Coh}<0.31)$ and is significant, but with a lower coherence than between the benthic $\delta^{18} \mathrm{O}$ record and 

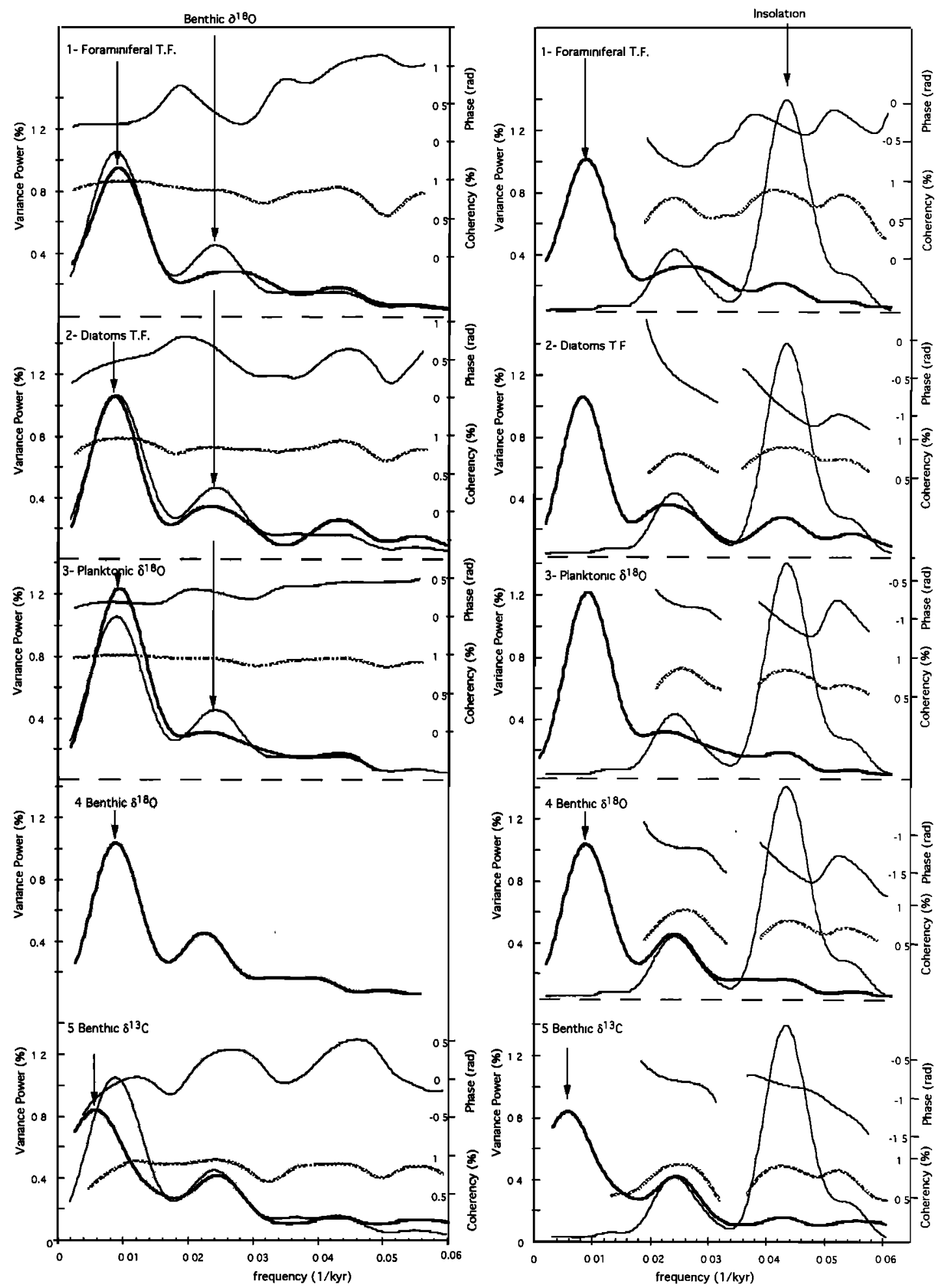

Figure 5. Results of the spectral analysis (Blackman-Tuckey) and cross correlation with the (left) benthic $\delta^{18} \mathrm{O}$ record and (right) insolation for (from top to bottom) foraminiferal SSST, diatom SSST, planktonic $\delta^{18} \mathrm{O}$, benthic $\delta^{18} \mathrm{O}$, and benthic $\delta^{13} \mathrm{C}$. Left scales show distribution of the relative variance power. Right scales show phases (in radians) and coherency. F.T. is transfer function. 


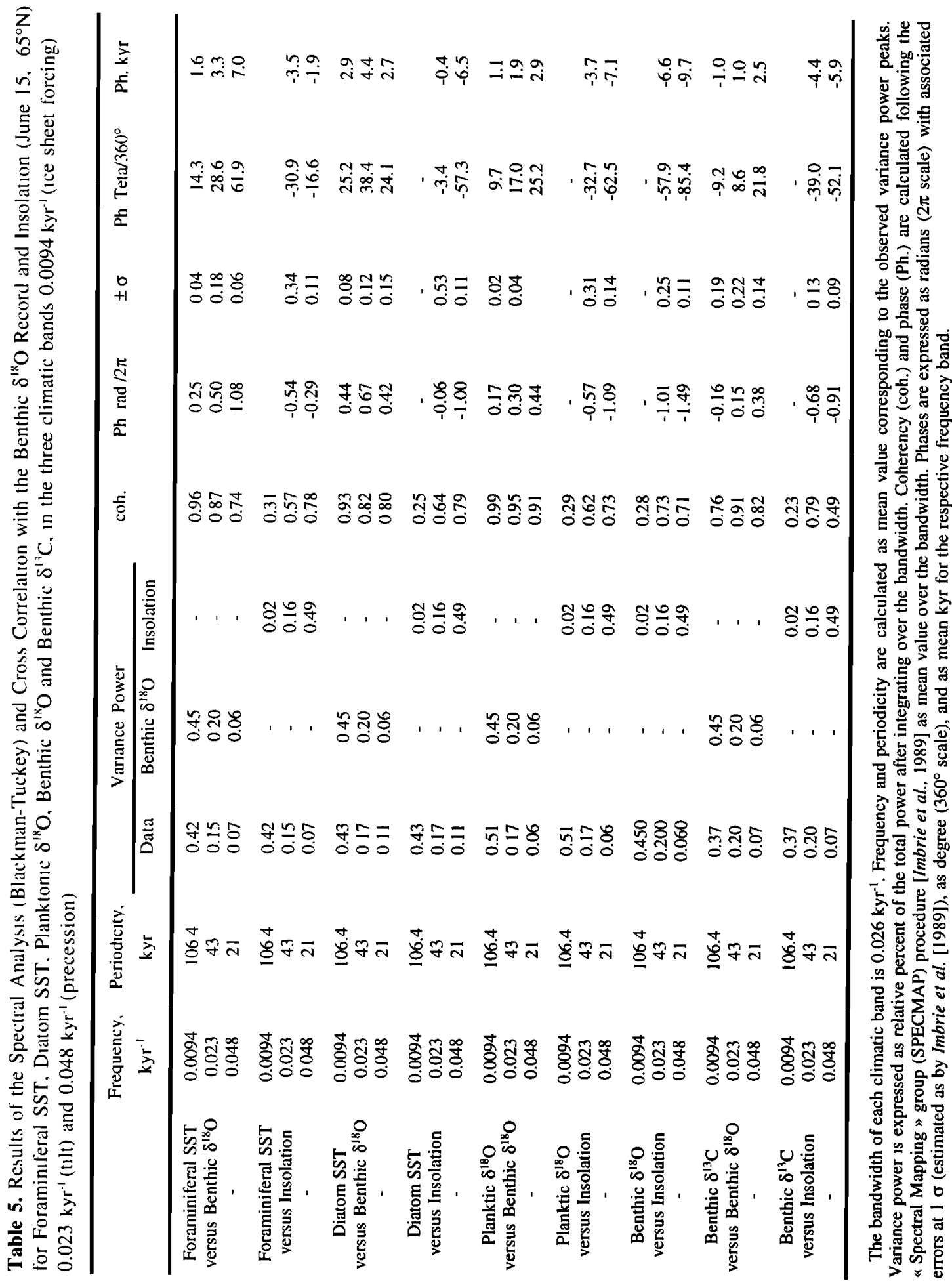


insolation, in the $1 / 43-\mathrm{kyr}^{-1}(0.56<\mathrm{Coh}<0.79)$ and $1 / 21-\mathrm{kyr}^{-1}$ $(0.71<$ Coh<0.88) bands. This is in agreement with the results of Imbrie et al. [1992, 1993]. The large coherent response of the various parameters with ice volume at $1 / 106 \mathrm{kyr}^{-1}$ is directly linked to the global influence of the large northern ice sheets, which have paced the climatic records at that frequency over most of the last $900 \mathrm{kyr}$. The response of the Southern Ocean proxies is also larger in the $1 / 43-\mathrm{kyr}^{-1}$ that in the $1 / 21-\mathrm{kyr}^{-1}$ bands. This is related to a recent study by Waelbroeck et al. [1995], in which the Vostok deuterium $\delta \mathrm{D}$ record (a proxy of the air temperature over Antarctica) is extended to $250 \mathrm{ka}$ and analysea in the SPECMAP temporal framework, by direct tuning with insolation in the $1 / 43-$ and $1 / 20-\mathrm{kyr}^{-1}$ bands. Their study show that the Vostok $\delta \mathrm{D}$ record has a larger fraction of the variability in the $1 / 43-\mathrm{kyr}^{-1}$ band than in the $1 / 100$ - and the $1 / 20-\mathrm{kyr}^{-1}$ bands, when compared to the marine series. This points to a direct effect of high-latitude southern insolation on the local changes in air and sea surface temperature.

When we consider the leads and lags between potential forcings and responses, the first important result is the systematic lead ( 1 to $3 \mathrm{kyr}$ ) of the planktonic versus the benthic foraminiferal $\delta^{18} \mathrm{O}$ records in the three frequency bands. Thus the choice of referring chronostratigraphy to benthic or planktonic foraminiferal records (as in SPECMAP files) has significant implications in the Southern Ocean. SSST leads the benthic foraminiferal $\delta^{18} \mathrm{O}$ record by about $3 \mathrm{kyr}$ for the diatom transfer function and $3 \mathrm{kyr}$ (at $1 / 43 \mathrm{kyr}^{-1}$ ) to $7 \mathrm{kyr}$ (at $1 / 21$ $\mathrm{kyr}^{-1}$ ) for the foraminiferal transfer function. This SSST lead is reduced to about 1-2 kyr when compared to the MD 88-770 planktonic $\delta^{18} \mathrm{O}$ record, in agreement with previously published results for RC11-120 and other Southern Ocean cores [Imbrie et al., 1992; 1993; Howard and Prell, 1992]. This result is not surprising since the planktonic foraminiferal $\delta^{18} \mathrm{O}$ signal is driven partly by SSST (the leading signal) and partly by global seawater $\delta^{18} \mathrm{O}$ (the lagging component), recorded by the benthic foraminiferal $\delta^{18} \mathrm{O}$. Our results imply that northern hemisphere ice sheets may participate but are not at the origin of the changes in Southern Ocean SSST in the obliquity and precession bands.

SSST (foraminiferal transfer function) lags maximum obliquity by $3.5 \mathrm{kyr}\left(31^{\circ}\right)$. This points to climatic processes with a time constant of several kiloyears, as the evolution of the peripheric extent of ice sheets or deep water formation and transport [Waelbroeck et al., 1995]. In the precession band, the foraminiferal SSST record lags the June 15 summer insolation by $2 \mathrm{kyr}\left(17^{\circ}\right)$. This corresponds to a change in Southern Ocean summer surface temperature in phase with July insolation (northern summer).

The diatom transfer function has a significantly different response, considering the \pm 1 - to $2-\mathrm{kyr}$ phase uncertainty calculated by the SPECMAP method (Table 5): it is approximatively in phase with insolation in the obliquity band but lags insolation by $6.5 \mathrm{kyr}$ in the precession band. This is to be related with the better sensitivity of the diatom transfer function to the cold polar water and sea ice variabilities. In that respect, it is acceptable that high-latitude southern surface waters are very sensitive to the direct influence of the obliquity modulation of seasonality. The larger lag in the precession band points also to a higher sensitivity of the diatom distribution to the local climatic influence of high-latitude processes with large time constant as the Antarctic ice sheet peripheral extent.

This still does not explain why the foraminiferal SSST signal, although less sensitive to the high-latitude processes, presents a larger lag in the obliquity band than the diatom SSST signal. If the results are taken at face value, they indicate that at least two processes influence the Southern Ocean climatology in the obliquity band: (1) locally, at high latitude, the sea ice coverage and SSST which react with no lags to changes in insolation; (2) at lower latitudes, the ice sheet peripheral extent and related atmospheric and deep water forming processes. In reverse, in the precessior band, the low-latitude insolation forcing would be the predominant factor for the foraminiferal SSST signal.

The phasing of the benthic foraminiferal $\delta^{13} \mathrm{C}$ response helps to define precisely the role of deep waters. The $\delta^{13} \mathrm{C}$ leads the benthic $\delta^{18} \mathrm{O}$ signal by 1 to $2.5 \mathrm{kyr}$ in both orbital bands but lags SSST by 2 to $5 \mathrm{kyr}$. Our results confirm earlier work by Pisias and Shackleton [1984] in the deep equatorial Pacific and by Charles and Fairbanks [1992] on the last deglaciation in the deep Southem Ocean: dissolved $\mathrm{CO}_{2}$ and its transfer to the atmosphere and continental biosphere occured early in the chain of events which drove to interglacials. But we demonstrated that surface water temperature changes occured before. The key to the early evolution of the Southern Ocean surface waters is therefore not to be found in deep water and its carbon cycle. The rather large phase of the benthic $\delta^{13} \mathrm{C}$ response to insolation, about $5 \mathrm{kyr}$ for the $1 / 43-\mathrm{kyr}^{-1}$ and $1 / 21-\mathrm{kyr}^{-1}$ bands, is compatible with our interpretation of the diatom and foraminiferal SST response: it is similar to the "slow" response mode of the foraminifera in the obliquity band and of the diatoms in the precession band which we have attributed to the peripheral evolution of the Antarctic ice sheet and its influence on atmospheric circulation and deep water formation.

\subsection{The Salinity Hypothesis}

In the northern hemisphere, one of the main characteristics of glacial periods is the formation of a frontal zone across the North Atlantic, with warm and saline waters to the south and cold and less saline polar waters to the north [CLIMAP, 1981, 1984; Duplessy et al., 1991, 1992b]. This front is associated with a large decrease of the NADW conveyor belt [Broecker and Denton, 1989]. Both effects efficiently lower the transfer of salt from the high-salinity intertropical Atlantic to the deep waters. Labeyrie et al. [1992] have shown that due to the relative salinity increase in warm water and salinity decrease in high-latitude cold surface and deep waters, the density gradients between saline subtropical waters and deep waters were probably much smaller during the last glacial. Therefore zones of open water convection (modal waters of McCartney [1977]) may have been more generalised near subtropical fronts, changing patterns of heat transfer to the atmosphere and atmospheric circulation.

The circumpolar frontal zone which limits the Southern Ocean to its north is wind driven and strongly linked to zonal sea surface temperature (SST) distribution. We may therefore consider that similar mechanisms have been operating in the northern and southern hemispheres, with a specific role for the sea surface salinity distribution. 
4.4.1. Calibration of the foraminiferal isotopic fractionation for estimation of sea surface salinity. Sea surface salinity can be derived from planktonic foraminiferal $\delta^{18} \mathrm{O}$ once corrected for the effect of temperature on isotopic fractionation (using transfer function estimates of SSST) and for the global changes in seawater $\delta^{18} \mathrm{O}$ [Labeyrie et al., 1986; Duplessy et al., 1991; Duplessy et al., 1992a,b]. We have checked the calibration developed by Duplessy et al. [1991] in the northern Atlantic Ocean by analysing the $\delta^{18} \mathrm{O}$ of shells of $N$. pachyderma s. and $G$. bulloides from Southern Ocean core tops and adding published values from the Southern Ocean [Howard and Prell, 1992; Grobe et al., 1990; Martinson et al., 1987] (Table 6). The "isotopic temperature," derived from the planktonic foraminifera $\delta^{18} \mathrm{O}$ using the equilibrium relationship of Shackleton [1974] is reported versus modern
SSST [Levitus, 1982] in Figure 6. North Atlantic values in the same temperature range are reported simultaneously [Duplessy et al., 1991]. These authors have shown that in the North Atlantic, planktonic foraminiferal $\delta^{18} \mathrm{O}$ follow the equilibrium relationship of Shackleton [1974] if the growth temperature $\left(\mathrm{T}^{*}\right)$ is taken at $-1^{\circ} \mathrm{C}$ (for $G$. bulloides) and $-2.5^{\circ} \mathrm{C}$ (for $N$. pachyderma s.), respectively, below summer sea surface temperature. Such apparent disequilibrium may be due to the subsurface habitat of $G$. bulloides and $N$. pachyderma s. in thermally stratified upper waters during summer or to a growing period restricted to the spring bloom. For the Southern Ocean core tops, G. bulloides and $N$. pachyderma s. have similar isotopic response, in agreement with a deeper mixed layer. Yet Duplessy et al.'s North Atlantic relationship is observed only for SSST greater than $+4^{\circ} \mathrm{C}$. Below $4^{\circ} \mathrm{C}$, isotopic temperatures

Table 6. Calibration of the Relation Between the Isotopic Temperature Derived from the $\delta^{18} \mathrm{O}$ in G. Bulloides and $N$. Pachyderma s. and Levitus [1982] Summer Sea Surface Temperatıre for Southern Ocean Core Tops

\begin{tabular}{|c|c|c|c|c|c|c|c|c|c|}
\hline Core & Latitude & Longitude & Foraminifera & $\delta^{18} \mathrm{O}$ & salinity & $\delta^{18} \mathrm{Ow}$ calc & $\mathrm{SSST},{ }^{\circ} \mathrm{C}$ & isotopic $\mathrm{T},{ }^{\circ} \mathrm{C}$ & reference \\
\hline E45-29 & $44^{\circ} 53^{\prime} \mathrm{S}$ & $106^{\circ} 31^{\prime} \mathrm{E}$ & Bulloides & 1.96 & 34.29 & -0.07 & 86 & 7.4 & 2 \\
\hline M269-965 & $60^{\circ} 54^{\prime} \mathrm{S}$ & $57^{\circ} 06^{\prime} \mathrm{W}$ & Pachy. & 3.20 & 34.00 & -024 & 08 & 2.0 & 6 \\
\hline MD 80-304 & $51^{\circ} 04^{\prime} \mathrm{S}$ & $67^{\circ} 44^{\prime} \mathrm{E}$ & Bulloides & 3.18 & 33.94 & -026 & 38 & 2.0 & 1 \\
\hline MD 80-304 & $51^{\circ} 04^{\prime} \mathrm{S}$ & $67^{\circ} 44 ' \mathrm{E}$ & Pachy. & 2.86 & 3394 & -0.26 & 3.8 & 32 & 1 \\
\hline MD $82-424$ & $54^{\circ} 06^{\prime} \mathrm{S}$ & $00^{\circ} 22^{\prime} \mathrm{W}$ & Pachy. & 3.48 & 3384 & -0.32 & 13 & 0.7 & 1 \\
\hline MD 84-551 & $55^{\circ} 00^{\prime} \mathrm{S}$ & $73^{\circ} 17^{\prime} \mathrm{E}$ & Bulloides & 296 & 33.90 & -0.28 & 21 & 28 & 1 \\
\hline MD 84-551 & $55^{\circ} 00^{\prime} \mathrm{S}$ & $73^{\circ} 17^{\prime} \mathrm{E}$ & Pachy. & 3.16 & 33.90 & -028 & 21 & 2.0 & 1 \\
\hline MD 84-552 & $54^{\circ} 55^{\prime} \mathrm{S}$ & $73^{\circ} 50^{\circ} \mathrm{E}$ & Bulloides & 2.90 & 33.90 & -0.28 & 21 & 3.0 & 1 \\
\hline MD 84-552 & $54^{\circ} 55^{\prime} \mathrm{S}$ & $73^{\circ} 50^{\prime} \mathrm{E}$ & Pachy. & 3.07 & 3390 & -0.28 & 21 & 2.3 & I \\
\hline MD $88-767$ & $46^{\circ} 40^{\prime} \mathrm{S}$ & $79^{\circ} 30^{\prime} \mathrm{E}$ & Bulloides & 201 & 34.50 & 0.05 & 82 & 7.6 & I \\
\hline MD 88-768 & $45^{\circ} 45^{\prime} \mathrm{S}$ & $82^{\circ} 56^{\prime} \mathrm{E}$ & Bulloides & 1.91 & 3461 & 0.11 & 98 & 82 & 1 \\
\hline MD $88-768$ & $45^{\circ} 45^{\prime} S$ & $82^{\circ} 56^{\prime} \mathrm{E}$ & Pachy. & 1.52 & 34.61 & 0.11 & 9.8 & 9.8 & 1 \\
\hline MD 88-769 & $46^{\circ} 04^{\prime S}$ & $90^{\circ} 07^{\prime} \mathrm{E}$ & Bulloides & 2.04 & 34.10 & -017 & 104 & 6.6 & I \\
\hline MD 88-769 & $46^{\circ} 04^{\prime} \mathrm{S}$ & $90^{\circ} 07 \mathrm{E}$ & Pachy. & 1.46 & 3410 & -017 & 104 & 89 & 1 \\
\hline MD $88-770$ & $46^{\circ} 01 S$ & $96^{\circ} 27 \mathrm{E}$ & Bulloides & 1.86 & 34.15 & -015 & 8.8 & 75 & 1 \\
\hline MD 88-770 & $46^{\circ} 01^{\prime} S$ & $96^{\circ} 28 \mathrm{E}$ & Pachy. & 177 & 34.15 & -0.15 & 8.8 & 7.8 & 1 \\
\hline MD 88-772 & $50^{\circ} 01^{\prime} \mathrm{S}$ & $104^{\circ} 53 \mathrm{E}$ & Bulloides & 2.59 & 3390 & -0.28 & 42 & 41 & 1 \\
\hline MD 88-773 & $52^{\circ} 54 ' \mathrm{~S}$ & $109^{\circ} 52 \mathrm{E}$ & Bulloides & 2.66 & 33.90 & -0.28 & 3.3 & 3.9 & 1 \\
\hline MD 88-773 & $52^{\circ} 54^{\prime} \mathrm{S}$ & $109^{\circ} 52 \mathrm{E}$ & Pachy. & 283 & 33.90 & -0.28 & 3.3 & 3.2 & 1 \\
\hline MD 88-784 & $54^{\circ} 12^{\prime} \mathrm{S}$ & $144^{\circ} 48^{\prime} \mathrm{E}$ & Bulloides & 2.64 & 3384 & -031 & 5.4 & 38 & 1 \\
\hline MD 88-784 & $54^{\circ} 12^{\prime} \mathrm{S}$ & $144^{\circ} 48^{\prime} \mathrm{E}$ & Pachy. & 2.84 & 3384 & -0.31 & 54 & 31 & 1 \\
\hline MD 88-787 & $56^{\circ} 23^{\prime} \mathrm{S}$ & $145^{\circ} 17^{\prime} \mathrm{E}$ & Pachy. & 2.66 & 33.81 & -0.33 & 4.3 & 3.7 & 1 \\
\hline MD 88-788 & $57^{\circ} 58^{\prime} \mathrm{S}$ & $144^{\circ} 35^{\prime} \mathrm{E}$ & Bulloides & 2.99 & 3383 & -032 & 3.6 & 25 & 1 \\
\hline MD 88-788 & $57^{\circ} 58^{\prime} \mathrm{S}$ & $144^{\circ} 35^{\prime} \mathrm{E}$ & Pachy. & 3.18 & & -0.32 & 36 & 18 & 1 \\
\hline MD $88 \mathrm{~K}-02$ & $45^{\circ} 45^{\prime} S$ & $82^{\circ} 56^{\prime} \mathrm{E}$ & Bulloides & 1.78 & 34.60 & 0.10 & 9.8 & 8.7 & 1 \\
\hline MD $88 \mathrm{~K}-02$ & $45^{\circ} 45^{\prime} \mathrm{S}$ & $82^{\circ} 56 \mathrm{E}$ & Pachy. & 2.22 & 3460 & 0.10 & 98 & 70 & 1 \\
\hline MD 88K-05 & & $109^{\circ} 55^{\prime} \mathrm{E}$ & Bulloides & 2.75 & 33.89 & -0.29 & 3.3 & 3.5 & 1 \\
\hline MD $88 K-10$ & $54^{\circ} 11^{\prime} \mathrm{S}$ & $144^{\circ} 47^{\prime} \mathrm{E}$ & Bulloides & 2.55 & 3384 & -031 & 54 & 4.2 & 1 \\
\hline MD $88 K-10$ & $54^{\circ} 11^{\prime} \mathrm{S}$ & $144^{\circ} 47^{\prime} \mathrm{E}$ & Pachy. & 2.76 & 3384 & -0.31 & 54 & 34 & 1 \\
\hline MD $88 \mathrm{~K}-13$ & $57^{\circ} 57^{\prime} \mathrm{S}$ & $144^{\circ} 35 \mathrm{E}$ & Pachy. & 3.13 & 33.83 & -0.32 & 3.6 & 2.0 & 1 \\
\hline MD80-KK63 & $51^{\circ} 56 \mathrm{~S}$ & $42^{\circ} 53 \mathrm{E}$ & Bulloides & 2.95 & 3387 & -0.30 & 26 & 27 & 1 \\
\hline MD80-KK63 & $51^{\circ} 56 ' S$ & $42^{\circ} 53 \mathrm{E}$ & Pachy. & 3.29 & 33.87 & -0.30 & 2.6 & 1.5 & 1 \\
\hline PS 13-87 & $68^{\circ} 44^{\prime} \mathrm{S}$ & $5^{\circ} 52^{\prime} \mathrm{W}$ & Pachy. & 3.59 & 33.54 & -0.48 & -1.0 & -02 & 3 \\
\hline PS 13-94 & $70^{\circ} 06^{\prime} \mathrm{S}$ & $6^{\circ} 51^{\prime} \mathrm{W}$ & Pachy. & 3.40 & 3350 & -050 & -10 & 0.4 & 3 \\
\hline PS 14-31 & $69^{\circ} 49^{\prime} \mathrm{S}$ & $6^{\circ} 35^{\prime} \mathrm{W}$ & Pachy & 3.46 & 3360 & -045 & -06 & 03 & 3 \\
\hline PS13-88 & $69^{\circ} 49^{\prime} \mathrm{S}$ & $6^{\circ} 35^{\prime} \mathrm{W}$ & Pachy. & 3.58 & 33.54 & -0.48 & -11 & -0.2 & 3 \\
\hline RC 13-254 & $48^{\circ} 34^{\prime} \mathrm{S}$ & $5^{\circ} 07^{\prime} \mathrm{E}$ & Pachy. & 2.50 & 3384 & -032 & 4.6 & 4.3 & 4 \\
\hline RC 13-269 & $52^{\circ} 37^{\prime} \mathrm{S}$ & $0^{\circ} 07^{\prime} \mathrm{E}$ & Pachy. & 2.80 & 33.84 & -032 & 18 & 32 & 4 \\
\hline RC11-120 & $43^{\circ} 31^{\prime} \mathrm{S}$ & $79^{\circ} 52 \mathrm{E}$ & Bulloides & 1.87 & 34.84 & 0.23 & 112 & 8.9 & 5 \\
\hline $\mathrm{RC} 13-271$ & $51^{\circ} 59^{\prime} \mathrm{S}$ & $4^{\circ} 3 l^{\prime} \mathrm{E}$ & Pachy. & 2.56 & 33.85 & -0.31 & 32 & $4 I$ & 4 \\
\hline V 22-108 & $43^{\circ} 11^{\prime S}$ & $3^{\circ} 15^{\prime} \mathrm{W}$ & Pachy. & 1.00 & 34.24 & -0.10 & 98 & 11.1 & + \\
\hline
\end{tabular}

Salinity (S) and summer (February) sea surface temperature (SSST) are interpolated from Levitus [1982]). The surface water $\delta^{\mid x}()$ $\left(\delta^{18} \mathrm{Ow}\right)$, is derived from the salinity following Cratg and Gordon [1965] relationship modified using the Geochemical Ocean Sectıons Study (GEOSECS) Southern Ocean data from Ostlün et al. [1987]: $\delta^{18} \mathrm{Ow}=-19.26+0.558 * S$. The isotopic temperatures (isotopic $T$ ) are derived from the foraminiferal $\delta^{18} \mathrm{O}$ following Shackleton [1974] equation. Reference are 1, Centre des Faibles Radioactivités, Gıf sur Yvette. 2. Howard and Prell [1992]; 3, Grobe et al. [1990]; 4, Shackleton (personal communication, 1986); 5, N. J Shackleton, as given by Martumson el al. [1987]; 6, sediment trap from Wefer et al. [1982]. 


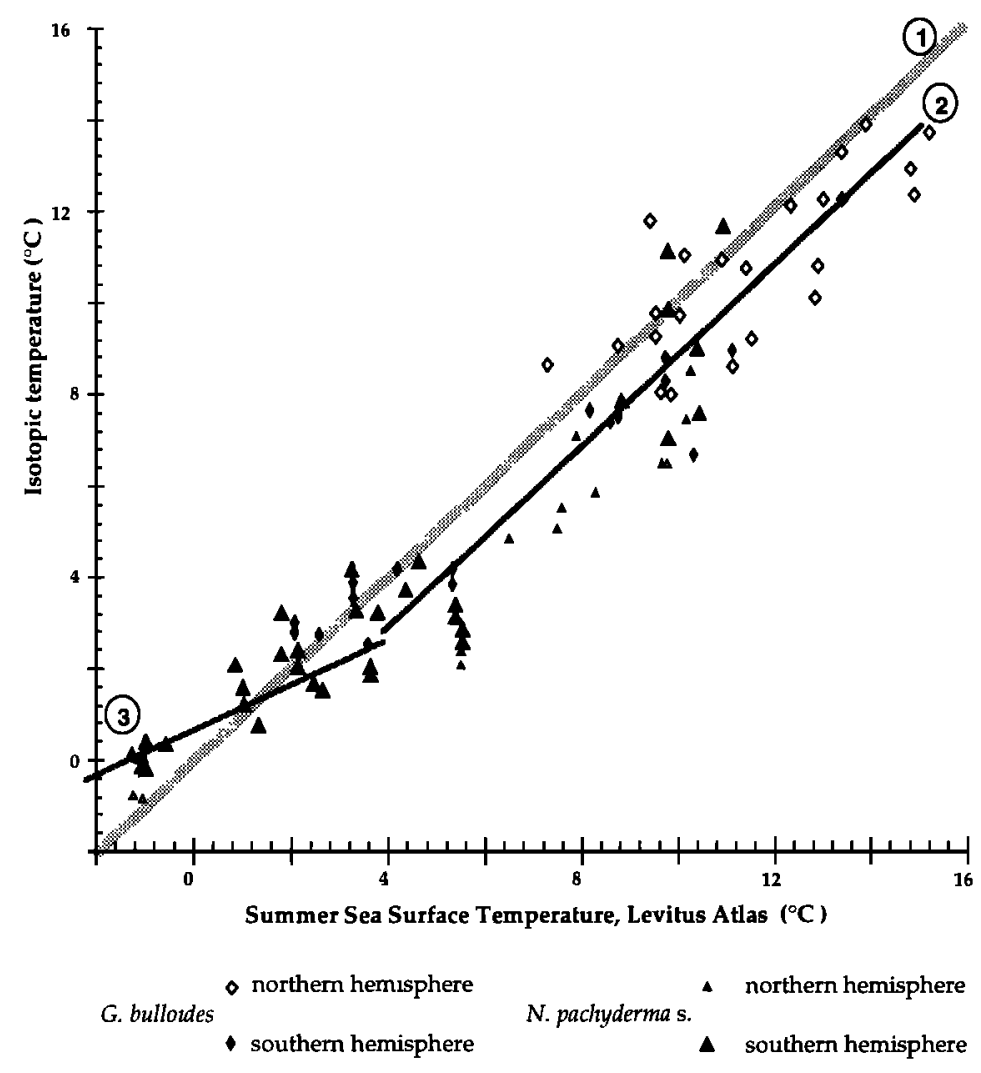

Figure 6. Calibration of the relation between isotopic temperature and modern [Levitus, 1982] summer (February) sea surface temperatures (SSST) for $N$. pachyderma s. and G. bulloides Holocene core tops (Table 6). Isotopic temperatures are derived from the shells $\delta^{18} \mathrm{O}$ using the relationship of Shackleton [1974]. North Atlantic values: a reported simultaneously [Duplessy et al. 1991]. The numbers 1, 2, and 3 indicate the equilibrium isotopic fractionation line from Shackleton [1974], the regression line between the isotopic and measured sea surface temperature for temperatures above $4.25^{\circ} \mathrm{C}$, and idem for temperatures below $4.25^{\circ} \mathrm{C}$, respectively.

converge progressively toward SSST (or becomes apparently even warmer for SSST below $+1^{\circ} \mathrm{C}$ ) as temperatures decrease. This may be explained by a shorter growing season limited to the warmer and better lighted midsummer months. We may approximate the evolution observed in the Southern Ocean using the empirical calibration (valid for both $G$. bulloides and N. pachyderma $\mathrm{s}$.): above SSST $=4.25^{\circ} \mathrm{C}, \mathrm{T}^{*}=\mathrm{SSST}-1$, and below SSST $=4.25^{\circ} \mathrm{C}, \mathrm{T}^{*}=0.6^{*} \mathrm{SSST}+0.7$ (Figure 6).

4.4.2. Changes in surface water $\delta^{18} O\left(\delta_{\text {sw }}\right)$ and salinity at the location of core MD 88-770. We follow, for the initial steps, the method described by Duplessy et al. [1992a,b]. Calculations are limited to levels where planktonic $\delta^{18} \mathrm{O}$ and foraminiferal derived SSST were both analysed with, in addition, a small number of levels where values can be estimated by interpolation because analysed samples were distant by no more than $2 \mathrm{~cm}$ vertically. All computations are done after smoothing by a Gaussian window of 4 levels half width and linear interpolation each $1 \mathrm{kyr}$. The water $\delta^{18} \mathrm{O}\left(\delta_{\mathrm{sw}}\right)$ is calculated by solving the equation which links water temperature and isotopic fractionation [Shackleton, 1974]:

$$
\mathrm{T}^{*}=16.9-4.38\left(\boldsymbol{\delta}^{18} \mathrm{O}_{\text {foraminffera }}-\delta_{\text {sw }}\right)+0.1\left(\delta^{18} \mathrm{O}_{\text {foraminfera }}-\delta_{\text {sw }}\right)^{2}
$$

The next step consists of substracting the changes in global seawater $\delta^{18} \mathrm{O}\left(\delta_{\mathrm{Gw}}\right)$ from the calculated $\delta_{\mathrm{sw}}$. Labeyrie et al., [1987] and Shackleton [1987] have built similar reference records for this global ice volume, using benthic and planktonic foraminiferal $\delta^{18} \mathrm{O}$ signals, respectively, from areas with negligible changes in water temperature during glacialinterglacial transitions. We cannot directly use these records, because both $\delta_{\mathrm{Gw}}$ and $\delta^{18} \mathrm{O}_{\text {forammifera }}$ should be in the same timescale. We have no way to build such a timescale over the period of interest other than arbitrarily correlating $\delta_{\mathrm{Gw}}$ and $\delta^{18} \mathrm{O}_{\text {foramulfera }}$ since these records do not originate from the same core.

We propose therefore two different approachs: the first one, less precise, is applied on the complete MD 88-770 record; the second one, more precise, is focussed on glacial-interglacial comparisons.

4.4.2.1. The continuous signal: Two different models have buen built to derive $\delta_{\mathrm{G}_{w}}$ directly from the smoothed (4 points running mean) benthic foraminiferal $\delta^{18} \mathrm{O}$ record of core MD 88-770. They produce different signals, although both use the results of Fairbanks [1989], Labeyrie et al. [1987], and Shackleton [1987]. These authors have demonstrated, after Duplessy et al. [1980], that during the 
major glacial-interglacial transitions, significant changes in deep water temperature occured (of the order of 1 to $3^{\circ} \mathrm{C}$ ). These changes explain most of the differences observed between benthic foraminiferal $\delta^{18} \mathrm{O}$ records from the different oceanic basins but also the excess amplitude of the glacial-interglacial isotopic difference (1.65\% for MD 88-770), when compared to the estimated effect of sea level changes $\left(\Delta \delta_{\mathrm{G}_{\mathrm{w}}}=1.2 \% \mathrm{o}\right)$. Model 1 follows the hypothesis developed by Sowers et al. [1993]: the $-0.45 \%$ correction is applied by progressive steps of $0.09 \%$ o/kyr before and after interglacials $(11->6 \mathrm{ka}, 118->113$ ka, 131.5->126.5 ka, 196.5->193 ka, 217->213.5 ka, 235.5$>234 \mathrm{ka}$ ). Model 2 is derived from Labeyrie et al. [1987, 1991, 1995] and is based on the hypothesis that deep water temperature changes originate in the varying activity of the "warm" NADW, itself modulated by the extension of the northern ice sheets. Model 2 assumes that deep water temperature changes are proportional and in phase with ice volume changes. Thus, when expressed as changes relative to present, $\delta_{\mathrm{Gw}}=\left(\delta^{18} \mathrm{O}_{\text {bentuc coramumfera }}-3.4\right) * 1.2 / 1.65$. The timing of the main transitions resulting from models 1 and 2 is different by 1 to $3 \mathrm{kyr}$ (Figure 7a).

For both models, the resulting local difference in surface water $\delta^{18} \mathrm{O}, \Delta \delta_{\mathrm{sw}}=\delta_{\mathrm{sw}}-\delta_{\mathrm{Gw}}$, may be taken as a proxy for the local salinity anomaly (Figure $7 \mathrm{c}$ ). The amplitude of the signal depends on the model chosen, but the trends are mostly similar. Uncertainties are large, as $\Delta \delta_{\mathrm{sw}}$ is the residue of two successive subtractions (for the effects of SSST (Figure $7 b$ ) and $\delta_{G w}$ ) from the original planktonic foraminiferal $\delta^{18} \mathrm{O}$ signal. The calculated residual error on the smoothed signal is around $\pm 0.1 \%$ if all the short order variability is taken as stochastic analytical noise. The added, systematic error on global seawater $\delta^{18} \mathrm{O}$ is taken as $\pm 0.1 \%$. We extract therefore from this reconstruction the main trends of the salinity signal: most major warmings are associated with an increase in salinity (which appears in phase or slightly leading the warming). The same is true for the link between cooling trends and lowering in salinity. A simple explanation is that the SSST changes are associated with north/south shifts of surface saline subtropical waters and less saline polar waters.

4.4.2.2. Before and after major transitions: A more precise calculation can be done during periods of constant ice volume (maximum glacial and minimum interglacial), just prior to the major transitions of stages 6-5.5, 5.5-5.4, and 2-1. The domain for calculation is set by the stability of the benthic foraminiferal $\delta^{18} \mathrm{O}$ values around its maximum and minimum values. We take for interglacial seawater $\delta^{18} \mathrm{O}=0 \%$ (mean salinity 34.51) and for the glacial maximum $\delta^{18} \mathrm{O}=1.2 \%$ (mean salinity 35.55) [Labeyrie et al., 1987; Shackleton,

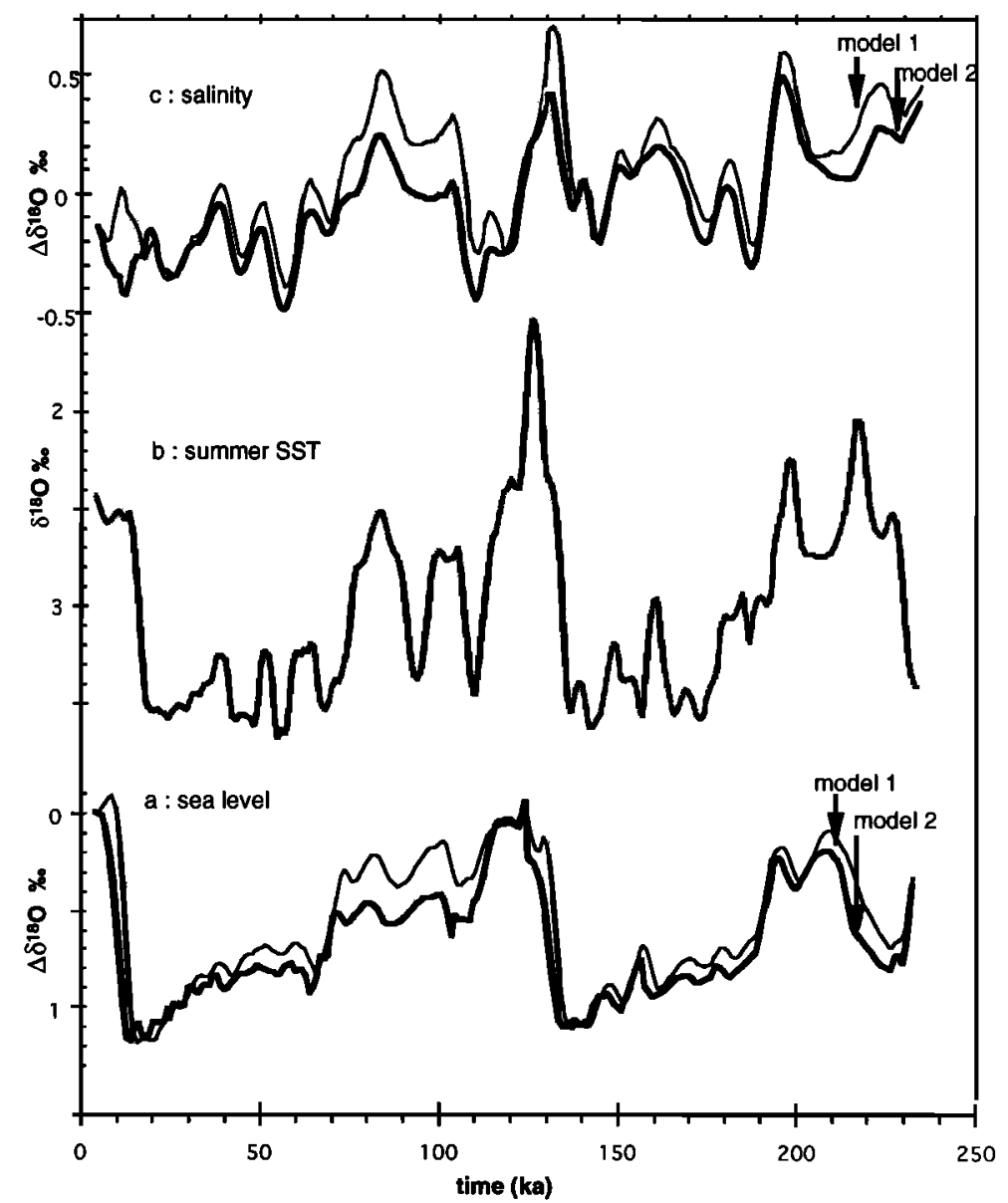

Figure 7. Changes over the last $230 \mathrm{ka}$ of (a) global seawater $\delta^{18} \mathrm{O}$ for models 1 and 2; (b) SSST (expressed in the $\delta^{18} O$ scale); (c) salinity (expressed as $\Delta \delta_{w}$ ) for models 1 and 2 . The shaded bands illustrate the covariance between SSST and salinity during major warmings. 
1987; Fairbanks, 1989]. Salinity is calculated using the relationship derived by Duplessy et al. [1991] from the Geochemical Ocean Sections Study (GEOSECS) atlas. Results are reported in Table 7 for the levels where the calculation is feasible (14.6-20.2 ka, 120.5-126.6 ka, and 135.5-145.3 ka). Salinity, during the glacial maxima of stages 6 and 2, oscillates around 34.4-34.9. Immediately prior (or simultaneously) to the warming initiation (around $138 \mathrm{ka}$ and $16.5 \mathrm{ka}$ ), salinity increases by about 1 , before it lowers due to the deglacial input. The salinity increase (to about 35.5 , with SSST around $5-6^{\circ} \mathrm{C}$, Table 7) is sufficient to induce, by winter cooling of these surface waters, equidensity with the deep waters [Labeyrie et al., 1992]. We have thus a potential source of open ocean deep water convection (the Mode waters of McCartney [1977]) at the latitude of core MD 88-770, at the beginning of the deglaciations.

At the end of the last interglacial (around $126.6 \mathrm{ka}$ in our timescale), salinity decreases by about 1 just after the main warm event. It is not possible by the present method to follow the evolution of salinity for the transition from stages 5.5 to 5.4 , because of the changes in global ocean $\delta^{18} \mathrm{O}$. The $\Delta \delta_{\mathrm{sw}}$ signal (Figure 7) indicates, however, that the lowered surface salinity lasted until the following warm stadial 5.3, linked probably to a northward invasion of polar waters during that period. Our results therefore support the hypothesis that most of the early SSST warming and cooling phases were linked to a north-south shift in the location of the main frontal zones, in agreement with the results of Howard and Prell [1992] in the same general area.

\subsection{Search for an Interhemispheric Link}

Both surface water warming and cooling phases occur before the corresponding increase and decrease in southern hemisphere summer insolation. Thus it would appear logical to neglect this climatic forcing for glacial-interglacial cycles and concentrate on forcing by the northern hemisphere summer insolation or by the low-latitude southern hemisphere winter insolation. We

Table 7. Southern Ocean Sea Surface Salinity at the Location of Core MD 88-770 During the Last Interglacial and the Last Two Glacial Maxima

\begin{tabular}{|c|c|c|c|c|c|c|c|}
\hline Age, ka & SSST, ${ }^{\circ} \mathrm{C}$ & $\mathrm{T}^{*},{ }^{\circ} \mathrm{C}$ & $\delta^{18} \mathrm{O}_{\text {forammintera }}$ & local $\delta^{18} \mathrm{Ow}$ & global $\delta^{18} \mathrm{Ow}$ & global salinity & local salınity \\
\hline $\begin{array}{l}14.64 \\
14.81\end{array}$ & $\begin{array}{l}6.7 \\
7.5\end{array}$ & $\begin{array}{l}5.7 \\
6.5\end{array}$ & $\begin{array}{l}2.76 \\
2.54\end{array}$ & $\begin{array}{l}0.31 \\
0.30\end{array}$ & $\begin{array}{l}1.2 \\
1.2\end{array}$ & $\begin{array}{l}35.56 \\
35.56\end{array}$ & $\begin{array}{l}33.96 \\
33.95\end{array}$ \\
\hline 14.97 & 7.2 & 6.2 & 2.85 & 0.52 & 1.2 & 35.56 & 34.34 \\
\hline 15.13 & 6.4 & 5.4 & 2.31 & -0.24 & 1.2 & 35.56 & 32.99 \\
\hline 15.46 & 7.2 & 6.2 & 2.80 & 0.48 & 12 & 3556 & 3428 \\
\hline 15.62 & 6.7 & 5.7 & 2.86 & 0.40 & 1.2 & 35.56 & 3413 \\
\hline 15.78 & 6.9 & 5.9 & 2.52 & 0.10 & 1.2 & 35.56 & 3359 \\
\hline 15.94 & 4.4 & 3.4 & 2.99 & -0.07 & 1.2 & 35.56 & 33.28 \\
\hline 16.11 & 6.8 & 5.8 & 3.70 & 1.27 & 1.2 & 35.56 & 35.69 \\
\hline 16.91 & 4.5 & 3.5 & 4.06 & 1.01 & 12 & 3556 & 35.22 \\
\hline 17.70 & 3.3 & 2.7 & 3.95 & 0.69 & 1.2 & 35.56 & 34.64 \\
\hline 18.25 & 3.3 & 2.7 & 3.90 & 0.63 & 1.2 & 35.56 & 3454 \\
\hline 18.64 & 3.8 & 3.0 & 3.73 & 0.55 & 1.2 & 35.56 & 34.39 \\
\hline 19.03 & 3.5 & 2.8 & 3.80 & 0.57 & 1.2 & 35.56 & 34.43 \\
\hline 19.41 & 3.7 & 2.9 & 3.88 & 0.68 & 1.2 & 3556 & 34.63 \\
\hline 19.79 & 3.6 & 2.9 & 3.83 & 0.62 & 1.2 & 35.56 & 3452 \\
\hline 20.18 & 3.1 & 2.6 & 3.73 & 0.44 & 1.2 & 35.56 & 3419 \\
\hline 121.05 & 8.1 & 7.1 & 1.78 & -0.32 & 0 & 34.52 & 33.95 \\
\hline 122.13 & 8.6 & 7.6 & 1.65 & -0.30 & 0 & 34.52 & 33.98 \\
\hline 123.22 & 7.1 & 61 & 1.74 & -0.60 & 0 & 34.52 & 33.44 \\
\hline 124.34 & 10.2 & 9.2 & 1.16 & -0.40 & 0 & 3452 & 33.80 \\
\hline 125.46 & 107 & 9.7 & 1.55 & 0.12 & 0 & 34.52 & 3473 \\
\hline 126.59 & 13.5 & 12.5 & 1.21 & 0.46 & 0 & 3452 & 3534 \\
\hline 135.46 & 3.4 & 2.8 & 3.45 & 0.21 & 1.2 & 35.56 & 3379 \\
\hline 135.89 & 3.8 & 3.0 & 3.87 & 0.70 & 1.2 & 35.56 & 34.66 \\
\hline 136.31 & 3.0 & 2.5 & 3.80 & 0.50 & 1.2 & 35.56 & 34.30 \\
\hline 136.73 & 3.1 & 2.6 & 3.66 & 0.37 & 12 & 35.56 & 34.06 \\
\hline 137.95 & 3.2 & 2.6 & 4.16 & 0.89 & 12 & 35.56 & 3500 \\
\hline 139.08 & 5.1 & 4.1 & 4.26 & 1.38 & 12 & 35.56 & 3588 \\
\hline 14018 & 3.6 & 2.9 & 4.05 & 0.84 & 1.2 & 3556 & 3492 \\
\hline 142.30 & 2.6 & 2.2 & 4.04 & 0.66 & 1.2 & 35.56 & 3459 \\
\hline 143.33 & 2.9 & 2.5 & 4.14 & 0.82 & 1.2 & 35.56 & 34.88 \\
\hline 144.34 & 2.8 & 2.4 & 3.51 & 0.17 & 1.2 & 35.56 & 33.71 \\
\hline 145.34 & 3.6 & 2.9 & 3.55 & 0.35 & 12 & 35.56 & 34.03 \\
\hline
\end{tabular}

Summer sea surface temperature (SSST) is estimated by the foraminiferal transfer function $\mathrm{T}^{*}$, the calıbrated isotopic temperature is defined as $T^{*}=$ SSST -1 for SSST $\geq 4.25^{\circ} \mathrm{C}$ and $\mathrm{T}^{*}=0.6^{*}$ SSST +0.7 for SSST $<4$. The local surface sea water $\delta^{18} \mathrm{O}$ is calculated as $\delta^{18} \mathrm{Ow}=\delta^{18} \mathrm{O}_{\text {foramminera }}+0.27-5^{*}\left(4.38-\left(4.38^{2}-0.4^{*}\left(16.9-\mathrm{T}^{*}\right)\right)^{05}\right.$. The mean global sea water $\delta^{18} \mathrm{O}$ (global $\delta^{18} \mathrm{Ow}$ ) is taken as $0 \%$ for interglacial and $+1.2 \%$ or glacial. Mean global salinity is calculated following Duplessy et al. [1991] as $S=34.52+1.04 *$ (global $\delta^{18} \mathrm{Ow}$ )/1.2. Local (surface) salinity is estımated by taking its difference to global salinity as proportional to the local sea water $\delta^{18} \mathrm{O}$ anomaly. 
have shown, however, that it is true in the precession band but not in the obliquity band, where the modulation of insolation affects probably directly the high-latitude surface waters (sea ice and SST) synchronously in both hemispheres. The following discussion is therefore limited to the precession band, although part of the climatic variability in the obliquity band may be driven by high-latitude northern hemisphere processes and transferred by the same links as those acting in the precession band.

4.5.1. The early warming of the surface Southern Ocean. As seen earlier, we may neglect the influence of northern hemisphere deep waters. The interhemispheric connection occurs therefore through the coupled ocean-atmosphere intertropical climate system. A typical example of the low-latitude connection is the cross equatorial transport of moisture in the Indian Ocean summer monsoon [Hastenrath, 1985]. Changes in northern hemisphere summer insolation drive not only the northern hemisphere southwestern monsoon winds but also the southern hemisphere southeastern trade wind and the associated increased evaporation in the southern subtropical Indian Ocean [Clemens and Oglesby, 1992; McIntyre et al., 1989; Schneider et al., 1995]. The resulting higher subtropical salinity may have contributed to an increase of salinity in the zone of the subpolar front, by surface transport in the Agulhas current. This would have facilitated open ocean convection at southern latitudes, heat transfer to the atmosphere and southward migration of the westerly belt and associated frontal system. Tests with coupled ocean-atmosphere models will be necessary to study such hypothetical chains of events. Guilderson et al. [1994] have recently proposed another atmospheric interhemispheric link: they have evidenced large temperature changes in the North Atlantic tropical surface waters early during the deglaciation. They suggest that the changes in cloudiness associated with this warming would sufficiently affect the low-latitude atmospheric albedo to synchronously influence both hemispheres.

4.5.2. The early cooling of the Southern Ocean at the beginning of a glacial cycle. Early cooling is also observed in the Norwegian Sea [Duplessy and Labeyrie, 1994; Cortijo et al., 1994]. For both high-latitude areas, cooling is associated with a large surface salınity drop (this work and Cortijo et al. [19941). The global chronostratigraphy is not sufficiently accurate for that period to know if both hemispheres responded completely in phase and with interdependent processes. We may, for example, consider that the Southern Ocean drop in salinity derives from increased melting of part of the Antarctic ice sheet during maximum warms and that a different scenario, such as a shift in sea ice distribution, occurred during approximately the same period in the Nordic Seas [Cortijo et al., 1994]. We may also consider that at least for the Southern Ocean, the processes at the origin of the early cooling are of the same nature (but inverse) as those associated with the early warming: a northward shift of the wind-driven frontal zone linked with the decrease in lowlatitude insolation. However, an immediate result of both evolutions is a global decrease in high-latitude thermohaline convection and transfer of heat to the atmosphere. This would introduce a positive feedback to the northern hemisphere decrease in insolation and to the cooling associated with the growth of the ice sheets.

\section{Conclusion}

Southern Ocean core MD 88-770 (46 $\left.01^{\circ} \mathrm{S} 96^{\circ} 28^{\prime} \mathrm{E}\right)$, which covers the last $230 \mathrm{kyr}$, has been analysed at high resolution to reconstruct the changes in surface and deep water hydrography in relation to the global glacial/interglacial cycles. The data presented here cover planktonic and benthic foraminiferal $\delta^{18} \mathrm{O}$, benthic foraminiferal $\delta^{13} \mathrm{C}$, and summer sea surface temperatures (SSST) estimated by transfer functions derived from the foraminifera and diatoms species distrıbution. Sea surface salinity is estimated from the planktonic foraminifera $\delta^{18} \mathrm{O}$ and SSST.

Our results demonstrate that

1. Changes in SSST lead those associated with deep water by 3 to $7 \mathrm{kyr}$ in the precession and obliquity bands, which indicate that changes in deep-water circulation are not at the origin of the Southern Ocean lead during climatic changes.

2. The diatom transfer function signal, which is more sensitive to high-latitude processes, covaries with insolation with zero lag in the obliquity band. This points to a direct role of the modulation of insolation by obliquity to change synchronously in both hemispheres the high-latitude surface water sea ice and SST.

3. Sea surface salinity increases at the beginning of a surface water warming and decreases at the beginning of the following cooling. We interpret this as an early north-south shift in the circumpolar frontal zones which separates the warm and salty subtropical waters and the cold and less saline polar waters during climatic transitions. This probably indicates early changes in the wind-driven ocean circulation.

We propose that the Southern Ocean rapid response to the changes in northern hemisphere insolation derives from the sensitivity of the circumpolar frontal zone to the changes in coupled surface ocean-atmosphere processes (heat, excess salinity, and wind forcing) driven by the exchange of energy between the atmosphere, surface ocean, and continents within the intertropical band.

Acknowledgments. This work is a direct output from the French Programme National de la Dynamique du Climat (Institut National des Sciences de l'Univers). It has greatly benefitted from the support of the Mission Scientıfique des Terres Australes et Antarctiques Françaises and Institut Français pour la Recherche et Technologie Polaire. Research in CFR-Gif is supported by Commissariat à l'Energie Atomique and Centre National de la Recherche Scientifique. Research in D.G.O.-Bordeaux is supported by CNRS and Université Bordeaux 1. Isotopic measurements are run by the team formed by B. Lecoat, J. Antignac, and J. Tessier. The role of $\mathrm{H}$. Leclaire in student training and micropaleontological control of the samples is also acknowledged. The paper has benefitted from the thorough reviews of $\mathrm{C}$. Waelbroeck, $\mathrm{P}$. de Menocal, and an anonymous reviewer, and considerable editonal help from $\mathrm{K}$. Miller. This is CFR publication 1718 .

\section{References}

Bard, E., M. Amold, J. Moyes, and J.-C. Duplessy, Reconstruction of the last deglaciation: Deconvolved records of $\delta^{18} \mathrm{O}$ profiles, micropaleontological variations, and accelerator ${ }^{14} \mathrm{C}$ dating, Clim. Dyn., $1,101-112,1987$.

Bard, E., L. Labeyrie, J.J. Pichon, M. Labracherie, M. Arnold, J. Duprat, J. Moyes, and J.C. Duplessy, The last deglaciation in the southern and northern hemispheres: A comparison based on $\delta^{18} \mathrm{O}$, sea surface temperature estimates and accelerator ${ }^{14} \mathrm{C}$ dating, in Geological 
History of the Polar Oceans: Arctic versus Antarctic, NATO ASI Ser. $C$, vol 308, edited by U. Bleil and J. Thiede, pp. 405-415, Kluwer Acad., Norwell, Mass, 1990.

Bard, E., M. Arnold, and R.G Fairbanks, ${ }^{230} \mathrm{Th}^{234} \mathrm{U}$ and ${ }^{14} \mathrm{C}$ ages obtained by mass spectrometry on corals, Radiocarbon, 35, 191-199, 1993

Broecker, W.S., and G.H. Denton, The role of ocean-atmosphere reorganizations in glacial cycles, Geochim. Cosmochm. Acta, 53 , 2465-2501, 1989

Charles, C.D., and R.G. Fairbanks, Glacial to interglacial changes in the isotopic gradients of Southem Ocean surface waters, in Geological History of the Polar Oceans Arctic versus Antarctic, NATO ASI Ser. $C$, vol 308, edited by U. Bleil and J. Thiede, pp. 519-538, Kluwer Acad., Norwell, Mass, 1990

Charles, C.D, and R.G. Fairbanks, Evidence from Southern Ocean sediments for the effect of North Atlantic deep water flux on climate, Nature, 355, 416-419, 1992.

Clemens, S.C., and R.J. Oglesby, Interhemispheric moisture transport in the Indian Ocean summer monsoon: Data-model and model-model comparisons, Paleoceanography, 7, 633-643, 1992.

Climate: Long-Range Investigation, Mapping, and Prediction (CLIMAP), Seasonal reconstructions of the Earth's surface at the last glacial maximum, GSA Map and Chart Ser., MC-36, Geol. Soc. of Am., Boulder, Colo., 1981

CLIMAP, The last interglacial ocean, Quat. Res., 21, 123-224, 1984.

Coplen, T.B., Normalization of oxygen and hydrogen isotope data, Chem. Geol. Isot. Geosci. Sect., 72, 293-297, 1988.

Cortijo, E., J.C. Duplessy, L. Labeyrie, H. Leclaire, J. Duprat, and T.C.E. van Weering, Eeemian cooling in the Norwegian Sea and North Atlantic preceding continental ice sheet growth, Nature, 372, 446449, 1994.

Craig, H., and A. Gordon, Deuterium and Oxygen 18 variations in the ocean and the marine atmosphere, in Stable Isotopes in Oceanic Studies and Paleotemperatures, edited by E. Tongiorgi, pp. 9-130, Cons. Natl. della Ric Pisa, Spoleto, Italy, 1965

Crowley, T.J , North Atlantic deep water cools the southern hemisphere, Paleoceanography, 7, 489-497, 1992

Curry, W.B., J.-C. Duplessy, L.D. Labeyrie, and N.J. Shackleton, Changes in the distribution of $\delta^{13} \mathrm{C}$ of deep water $\Sigma \mathrm{CO}_{2}$ between the last glaciation and the Holocene, Paleoceanography, 3, 317-341, 1988.

Duplessy, J.C., and L.D. Labeyrie, Surface and deep water circulatıon changes during the last climatic cycle, in Long term climatic variations, data and modelling, NATO ASI ser. I, vol. 22, edited by J. C. Duplessy, pp. 277-298, Springer-Verlag, New York, 1994.

Duplessy, J.C., J. Moyes, and C. Pujol, Deep water formation in the North Atlantic Ocean during the last ice age, Nature, 286, 479-482, 1980

Duplessy, J.C., N.J. Shackleton, R.K. Matthews, W.L. Prell, W.F. Ruddiman, M. Caralp, and $C$. Hendy, ${ }^{13} \mathrm{C}$ record of benthic foraminifera in the last interglacial ocean: Implications for the carbon cycle and the global dep water circulation, Quat. Res., 21 . 225-243, 1984

Duplessy, J.C., N.J. Shackleton, R.G. Fairbanks, L.D. Labeyrie, D. Oppo, and N. Kallel, Deepwater source variations during the last climatic cycle and their impact on the global deepwater circulation, Paleoceanography, 3, 343-360, 1988.

Duplessy, J.C., L.D. Labeyrie, A. Juillet-Leclerc, F. Maitre, J. Duprat, and $M$. Sarnthein, Surface salinity reconstruction of the north Atlantic Ocean during the last glacial maximum, Oceanol. Acta, 14. 311-324, 1991.

Duplessy, J.C., L.D Labeyrie, M. Arnold, M. Paterne, J. Duprat, and T.C.E. van Weering, Changes in surface salinity of the North Atlantic Ocean during the last deglasiation, Nature, 358, 485-488, 1992a.

Duplessy, J.C., L.D. Labeyrie, A. Juillet-Leclerc, and J. Duprat, A new method to reconstruct sea surface salinity: Application to the northern Atlantic ocean during the Younger Dryas, in The Last Deglaciation : Absolute and Radiocarbon Chronologies, NATO ASI Ser. I, vol. 2, edited by E. Bard and W. Broecker, pp. 201-218, Springer-Verlag, New York, 1992b.

Fairbanks, R.G., A 17,000 year glacio-eustatic sea level record Influence of glacial melting rates on the Younger Dryas event and deep ocean circulation, Nature, 342, 637-642, 1989.
Gordon, A.L., E.J. Molinelli, and T.N. Baker, Southern Ocean Atlas, 233 pp., Natl Sci. Found., Washington, D.C., 1982.

Grobe, H., A. Mackensen, H.-W. Hubberten, V. Spiess, and D. K Fuitterer, Stable isotope record and late Quaternary sedimentation rates at the Antarctic continental margin, in Geologic History of the Polar Oceans : Arctic versus Antarctic, NATO ASI Ser. C, vol. 308, edited by U. Bleil and J. Thiede, pp. 539-572, Kluwer Acad., Norwell, Mass., 1990

Guilderson T. P., R. G. Fairbanks, and J L. Rubenstone, Tropical temperature variations since 20,000 years ago: Modulating interhemispheric climate changes, Science, 263, 663-665, 1994

Hastenrath, S., Climate and Circulation of the Tropics, 455 pp., D. Reidel, Norwell, Mass., 1985

Hays, J D., J. Imbne, and N. J. Shackleton, Variations in the Earth's orbit: Pacemakers of the ice ages, Science, 194, 1121-1132, 1976.

Howard, W R., and W. L. Prell, A comparison of radiolarian and foraminiferal paleoecology in the southern Indian Ocean: New evidence for the interhemispheric timing of climatic change, Quat. Res., 21, 244-263, 1984

Howard, W. R., and W. L. Prell, Late Quaternary surface circulation of the southern Indian Ocean and its relationship to orbital vanations. Paleoceanography, 7, 79-117, 1992.

Hut, G., Stable isotope reference samples for geochemical and hydrological investigations, Consultant Group Meeting IAEA, Vienna 16-18 Sept 1985, Report to the Director General, Int. Atomic Energy Agency, Vienna, 1987.

Imbre, J., A theoretical framework for the Pleistocene ice ages, $J$ Geol. Soc. London, 142, 417-432, 1985.

Imbrie, J., and N.G. Kipp, A new micropaleontological method for paleoclimatology: Application to a late Pleistocene Caribbean core, in The Late Cenozoic Glacial Ages, edited by K.K. Turekian, pp. 71 181, Yale Univ. Press, New Haven, Conn., 1971.

Imbrie, J., J. D. Hays, D. G. Martinson, A. McIntyre, A. C. Mix, J. J. Morley, N. G. Pisias, W. L. Prell, and N. J. Shackleton, The orbital theory of Pleistocene climate: Support from a revised chronology of the marine $\delta^{18} \mathrm{O}$ record, in Milankovitch and Climate, Part 1, edited by A.L. Berger et al., pp. 269-305, D. Riedel, Norwell, Mass, 1984

Imbrie, J., A. McIntyre, and A. Mix, Oceanic response to orbital forcing in the late Quaternary: Observational and experimental strategies, in Climate and Geosciences, NATO ASI Ser. C, vol 285, edited by A Berger, S. Schneider and J.C. Duplessy, pp. 121-164, Kluwer Acad., Norwell, Mass., 1989.

Imbrie, J. et al., On the structure and origin of major glaciation cycles, 1 , Linear responses to Milankovitch forcing, Paleoceanography, 7 , $701-738,1992$.

Imbrie, J. et al., On the structure and origin of major glaciation cycles, 2 The 100,000 year cycle, Paleoceanography, 8, 699-735, 1993.

Jenkins, G.M., and D.G. Watts, Spectral Analysis and Its Applications, 525 pp., Holden-Day, Merrifield, Va., 1968.

Labeyne, L. D., and J.C. Duplessy, Changes in the oceanic ${ }^{13} \mathrm{C} /{ }^{12} \mathrm{C}$ ratio during the last 140,000 years: High-latitude surface records, Paleogeogr. Paleoclimatol. Paleoecol., 50, 217-240, 1985.

Labeyrie, L. D., J. J. Pichon, M. Labracherie, P. Ippolito, J. Duprat, and J.C. Duplessy, Melting history of Antarctica during the past 60,000 years, Nature, 322, 701-706, 1986.

Labeyrie, L. D., J.C. Duplessy, and P. L. Blanc, Variations in mode of formation and temperature of oceanic deep waters over the past 125,000 years, Nature, 327, 477-482, 1987.

Labeyrie, L. D., A. Juillet.-Leclerc., N. Kallel, and P. L. Blanc, Sea level and oceanic thermohaline circulation: Changes over a glacial/interglacial cycle, in Klimageschichtliche Probleme der letzten 130000 Jahre, edited by B. Frenzel, pp. 197-214, FisherVerlag, Stuttgart, Germany, 1991.

Labeyrie, L.D., J.C. Duplessy, J. Duprat, A.J. Juillet-Leclerc, J. Moyes, E. Michel, N. Kallel, and N.J. Shackleton, Changes in the vertical structure of the North Atlantic ocean between glacial and modern times, Quat. Sci. Rev. I1, 401-413, 1992.

Labeyrie, L. et al., Surface and deep hydrography of the Northern Atlantic Ocean dunng the last $150 \mathrm{kyr}$, Philos. Trans. Roy. Soc. London, B, 348, 255-264, 1995

Labracherie, M., L. D. Labeyrie, J. Duprat, E. Bard, M. Arnold, J.J. Pichon, and J.C. Duplessy, The last deglaciation in the Southern Ocean, Paleoceanography, 4, 629-638, 1989. 
Levitus, S., Climatological Atlas of the World Ocean, 173 pp., Natl. Oceanic and Atmos. Admin., Rockville, Md., 1982.

Martınson, D.G., W. Menke, and P. Stoffa, An inverse approach to signal correlation, J. Geophys Res., 87, 4807-4818, 1982.

Martinson, D.G., N.G. Pisias, J.D. Hays, J. Imbrie, T.C. Moore, and N.J. Shackleton, Age dating and the orbital theory of the ice ages: Development of a high-resolution 0-300,000 year chronostratigraphy, Quat. Res., 27, 1-30, 1987.

McCartney M. S, Subantactic mode water, in A Voyage of Discovery, edited by A. Angel, pp. 103-1 19, Pergamon, Tanytown, N.Y., 1977.

McIntyre, A., W. F. Ruddiman, K. Karlin, and A. C. Mix, Surface water response of the equatorial Atlantic Ocean to orbital forcing, Paleoceanography, 4, 19-55, 1989.

Michel E., L. Labeyrie, J.C. Duplessy, N. Gorfti, M. Labracherie, and J.L. Turon, Could deep subantarctic convection feed the world deep basins during the last glacial maximum?, Paleoceanography, in press, 1995.

Ostlünd, H.G., C. Craig, W.S. Broecker, and D. Spencer (Eds.), GEOSECS Atlantic, Pacific, and Indian Ocean Expeditions. Shorebased Data and Graphics, GEOSECS Atlas Series, vol. 7, 200 pp., U.S. Gov. Print. Off., Washington, D.C., 1987.

Pichon, J.J., M. Labracherie, L.D. Labeyrie, and J. Duprat, Transfer functions between diatom assemblages and surface hydrology in the Southern Ocean, Paleogeogr. Paleoclimatol. Paleoecol., 61, 79-95, 1987.

Pichon, J.J., L.D. Labeyrie, G. Bareille, M. Labracherie, J. Duprat, and J. Jouzel, Surface water temperature changes in the high latitudes of the southern hemisphere over the last glacial-interglacial cycle, Paleoceanography, 7, 289-318, 1992.

Pisias, N.G., and N.J. Shackleton, Modelling the global climate response to orbital forcing and atmospheric carbon dioxide changes, Nature, 310.757-759, 1984.

Pisias, N G., D G. Martinson, T.C. Moore, N.J. Shackleton, W.L. Prell, J. Hays, and $G$ Boden, High resolution stratigraphic correlation of benthic oxygen isotope records spanning the last 300,000 years, $\mathrm{Mar}$ Geol, 56, 119-136, 1984.

Prell, W L, The stability of low-lattude sea-surface temperatures: an evaluation of the CLIMAP reconstruction with emphasis on the positive SST anomalies, Rep. TR 025, U.S. Dep. of Energy, Washington, D.C., 1985.

Schneider, R. R., P. J. Müller, and G. Ruhland, Late Quaternary surface circulation in the east equatorial South Atlantic: Evidence from alkenone sea surface temperatures, Paleoceanography, 10, 197-219, 1995.

Shackleton, N.J., Oxygen isotope analysis and pleistocene temperatures reassessed, Nature, 215, 15-17, 1967
Shackleton, N.J., Attainment of isotopic equilibrium between ocean water and the benthonic foramunifera genus Uvigenna: Isotopic changes in the ocean during the last glacial, in Les Méthodes Quantitatives d'Etude des Variatıons du Clımat au Cours du Pléistocène., coll. CNRS, edited by J. Labeyrie, pp. 203-210, Cent. Nat. de la Rech. Sci., Paris, 1974.

Shackleton, N.J., Oxygen isotopes, ice and sea level, Quat. Sci. Rev., 6, 183-190, 1987.

Shackleton, N.J., and N. G. Pisias, Atmospheric carbon dioxıde, orbital forcing, and climate, in The Carbon Cycle and Atmospheric $\mathrm{CO}_{2}$ : Natural Variations Archean to Present, Geophys. Monogr. Ser., vol. 32, edited by E. Sundquist and W.S. Broecker, pp. 303-317, AGU, Washington, D.C., 1985.

Sowers, T., M.L. Bender, L.D. Labeyrie, D. Martinson, J. Jouzel, D. Raynaud, J.J. Pichon, and Y.S. Korotkevich, 135,000 year VostokSPECMAP common temporal framework, Paleoceanography, 8. 737-766, 1993.

Toggweiler, J. R., and J. L. Sarmento, Glacial to interglacial changes in atmospheric carbon dioxide: The critical role of ocean surface water in high latitudes, in The Carbon Cycle and Atmospheric $\mathrm{CO}_{2}$ : Natural Variations Archean to Present, Geophys. Monogr. Ser., vol. 32, edited by E. Sundquist and W.S. Broecker, pp. 163-184, AGU, Washington, D.C., 1985.

Waelbroeck, C., J. Jouzel, L. Labeyne, C. Lorius, M. Labracherie, M. Stiévenard, and N. I. Barkov, Comparing the Vostok ice deuterium record and series from Southem Ocean core MD 88-770 over the last two glacial-interglacial cycles, Clim. Dyn., in press, 1995.

Wefer, G., E. Suess, W Balzer, G. Liebezeit, P.J. Muller, C A. Ungerer, and $W$. Zenk, Fluxes of biogenic components from sediment trap deployment in circumpolar waters of the Drake Passage, Nature, 299, 145-147, 1982.

M. Arnold, J.C. Duplessy, N. Gorfti, L. Labeyrie, E. Michel, and M. Paterne, Centre des Faibles Radioactivités, Laboratoire mixte CNRSCEA, Domaine du CNRS 91198 Gif/Yvette cedex France. (e-mail: arnold@cfr.cnrs-gif.fr; duplessy@cfr.cnrs-gif.fr; labeyrie@cfr.cnrsgif.fr; michel@cfr.cnrs-gif.fr; paterne@cfr.cnrs-gif.fr)

M. Caralp, J. Duprat, M. Labracherie, J.J. Pichon, J.L. Turon, and M. Vautravers, Dept. de Géologie et Océanographie, Université Bordeaux 1, 33405 Talence France (e-mail: labracherie@geocean.u-bordeaux.fr; pichon@geocean.u-bordeaux.fr; turon@geocean.u-bordeaux.fr)

(Received August 31, 1994; revised June 5, 1995; accepted July 20, 1995) 